\title{
Deficiency in Complement C1q Improves Histological and Functional Locomotor Outcome after Spinal Cord Injury
}

\author{
Manuel D. Galvan, ${ }^{1,2}$ Sabina Luchetti, ${ }^{1,2}$ Adrian M. Burgos, ${ }^{1,2}$ Hal X. Nguyen, ${ }^{1,2}$ Mitra J. Hooshmand, ${ }^{1,2}$ \\ Frank P. T. Hamers, ${ }^{3}$ and Aileen J. Anderson ${ }^{1,2}$ \\ Departments of ${ }^{1}$ Physical Medicine \& Rehabilitation and ${ }^{2}$ Anatomy \& Neurobiology, Reeve-Irvine Research Center, University of California, Irvine, Irvine, \\ California 92697-4292, and 'Rehabilitation Hospital “DE Hoogstraat," Rudolf Magnus Institute of Neuroscience, 3583 TM Utrecht, The Netherlands
}

\begin{abstract}
Although studies have suggested a role for the complement system in the pathophysiology of spinal cord injury (SCI), that role remains poorly defined. Additionally, the relative contribution of individual complement pathways in SCI is unknown. Our initial studies revealed that systemic complement activation was strongly influenced by genetic background and gender. Thus, to investigate the role of the classical complement pathway in contusion-induced SCI, male C1q knock-out (KO) and wild-type (WT) mice on a complement sufficient background (BUB) received a mild-moderate T9 contusion injury with the Infinite Horizon impactor. BUB C1q K0 mice exhibited greater locomotor recovery compared with BUB WT mice $(p<0.05)$. Improved recovery observed in BUB C1q KO mice was also associated with decreased threshold for withdrawal from a mild stimulus using von Frey filament testing. Surprisingly, quantification of microglia/ macrophages (F4/80) by FACS analysis showed that BUB C1q KO mice exhibited a significantly greater percentage of macrophages in the spinal cord compared with BUB WT mice $3 \mathrm{~d}$ post-injury $(p<0.05)$. However, this increased macrophage response appeared to be transient as stereological assessment of spinal cord tissue obtained $28 \mathrm{~d}$ post-injury revealed no difference in F4/80-positive cells between groups. Stereological assessment of spinal cord tissue showed that BUB C1q KO mice had reduced lesion volume and an increase in tissue sparing compared with BUB WT mice $(p<0.05)$. Together, these data suggest that initiation of the classical complement pathway via $\mathrm{Clq}$ is detrimental to recovery after SCI.
\end{abstract}

Key words: complement system; C1q; spinal cord injury; inflammation; transgenic mice; locomotor function

\section{Introduction}

Traumatic injury to the CNS elicits a potent inflammatory response that can have diverse and opposing effects (Crutcher et al., 2006; Donnelly and Popovich, 2008). Components of both the innate and adaptive immune system have been implicated in influencing outcome after SCI (Farooque et al., 2001; Ma et al., 2002; Wells et al., 2003; Casha et al., 2005; Ackery et al., 2006; Kigerl et al., 2006; Genovese et al., 2008). Critically, the complement system, a component of the innate immune system capable of modulating the inflammatory response (Carroll, 2004; Morgan et al., 2005), has not been thoroughly investigated in SCI.

We have previously shown immunoreactivity for C1q, Factor B, C4 and C5b-9 within $24 \mathrm{~h}$ and extending through 6 weeks post-SCI (Anderson et al., 2004). In addition, complement proteins have been shown to be elevated in SCI patients (Rebhun et al., 1991). To date, studies investigating the role of complement in SCI have focused exclusively on complement C3. Complement C3 has been suggested to play an important role in SCI, based on studies either inhibiting this molecule using Vaccinia Virus Com-

\footnotetext{
Received June 19, 2008; revised Sept. 29, 2008; accepted 0ct. 24, 2008

This work was supported by National Institute of Neurological Disorders and Stroke (ROI NS43428-01) (A.J.A.).

Correspondence should be addressed to Aileen J. Anderson, Departments of Physical Medicine \& Rehabilitation and Anatomy \& Neurobiology, University of California, Irvine, 1107 Gillespie Neuroscience Research Facility, Irvine, CA 92697-4540.E-mail: aja@uci.edu.

DOI:10.1523/JNEUROSCI.2823-08.2008

Copyright $\odot 2008$ Society for Neuroscience $\quad 0270-6474 / 08 / 2813876-13 \$ 15.00 / 0$
}

plement Control Protein (VCP) (Reynolds et al., 2003; Reynolds et al., 2004) or C3 knock-out mice (Qiao et al., 2006). Complement C3 is the key convergence point for activation of the classical, lectin and alternative complement pathways. For example, classical complement activation via $\mathrm{Clq}$ leads to the sequential formation of the enzymatically active C3 and C5 convertases that cleave C3 and C5 respectively. Assembly of the C3 convertase leads to generation of the $\mathrm{C} 3 \mathrm{a}, \mathrm{C} 4 \mathrm{a}$, and $\mathrm{C} 5 \mathrm{a}$ anaphylatoxins, assembly of the C5 convertase, and ultimately assembly of C5b-9, the lytic membrane attack complex (MAC). However, it is unclear from these studies, which complement initiation pathways are involved in vivo and whether activation of these different pathways may be beneficial or detrimental to recovery after SCI.

Although C3 protein and activity levels appear to be sufficient across different mouse strains (Osmers et al., 2006), studies have previously shown that common mouse strains are constitutively deficient in total hemolytic complement activity (Ong and Mattes, 1989; Ong et al., 1992; Osmers et al., 2006). In addition, mouse serum exhibits less lytic function compared with rat and human serum in standard complement hemolytic CH50 assays (Ong and Mattes, 1989; Ong et al., 1992; Osmers et al., 2006). Thus, in experimental conditions using mice that are deficient in terminal complement lytic activity, significant components of the inflammatory response may be altered. These include C5amediated inflammatory cell recruitment and death of cells susceptible to MAC such as neurons and oligodendrocytes. Addi- 
tionally, because activation of the terminal complement pathway has been suggested to feedback in an amplification loop onto earlier segments of the complement cascade (Tran et al., 2002; Ramaglia et al., 2007), the overall picture of the contribution of complement to disease and injury models may be significantly altered in mouse strains that lack a complete functional complement system.

Accordingly, to investigate the contribution of the classical complement pathway in the pathogenesis of SCI, we have backcrossed complement C1q knock-out (KO) mice onto a complement sufficient background (BUB-BnJ, verified as $99.9 \%$ congenic via microsatellite marker analysis) for the analyses presented here. This study demonstrates that deficiency in the recognition component of the classical complement pathway (C1q) improves locomotor recovery and reduces secondary tissue damage after contusion-induced SCI in BUB mice. Improved recovery observed in $\mathrm{BUB} \mathrm{Clq} \mathrm{KO}$ mice was also associated with a decreased threshold for withdrawal from a mild stimulus using von Frey filament testing. Surprisingly, BUB C1q KO mice exhibited a transient increase in microglia/macrophages shortly after injury compared with BUB wild-type (WT) mice. These data support the hypothesis that complement activation via the classical complement pathway plays a crucial role in recovery after SCI.

\section{Materials and Methods}

Subjects. C1q KO mice on a mixed C57BL/6 background were generously provided by Andrea Tenner with permission by Marina Botto (Botto et al., 1998). C1q KO mice were backcrossed onto the BUB/BnJ strain at Charles River (San Diego, CA facility) using marker-assisted accelerated backcrossing (MAX-BAX) and using a set of chromosomal markers derived from the $\mathrm{BUB} / \mathrm{BnJ}$ strain and flanking the region adjacent to the C1q locus to obtain a congenic strain $(99 \% \mathrm{BUB} / \mathrm{BnJ}$, which is equivalent to $n=10$ generations by standard backcross). Animals from two separate breeding rounds and therefore two separate surgical dates were combined for both locomotor behavioral analysis and histological/stereological quantification.

All mice were allowed access to normal chow and were maintained on acidified water, $\mathrm{pH}$ 6.5, immediately upon arrival and throughout the duration of the study. Mice were given acidified water to reduce signs of urolithiasis. $\mathrm{BUB} / \mathrm{BnJ}$ male mice are prone to developing urolithiasis, which could result in further bladder complications after SCI. After SCI, rodents temporarily lose bladder function, and thus require manual bladder expression; male mice being more difficult to express after SCI than females of the same species. Providing acidified water to male BUB/ $\mathrm{BnJ}$ mice in combination with prophylactic administration of antibiotics $2 \mathrm{~d}$ before surgery minimized bladder complications and mortality. All mice were allowed to acclimate for a period of 2 weeks in the vivarium before undergoing surgical procedures. All procedures were conducted in accordance with Institutional Animal Care and Use Committee guidelines.

Injury paradigm. Preliminary studies in our laboratory showed that $\mathrm{BUB} / \mathrm{BnJ}$ male mice were prone to developing severe urolithiasis after a moderate contusion injury 50 kilodyne $(\mathrm{kd})(1$ dyne $=10 \mu \mathrm{N})$. This condition makes it extremely difficult to manually void their bladders, which can greatly compromise the health of the animals and the ability to conduct accurate behavioral assessment. Although we were able to alleviate some of these complications by providing $\mathrm{BUB} / \mathrm{BnJ}$ mice with acidified water, $\mathrm{pH} 6.5$, we were unable to completely eliminate urolithiasis by this method. Accordingly, in a preliminary experiment we tested whether a milder contusion injury would help alleviate bladder complications in these male mice. Based on the resulting data, we selected a 40 $\mathrm{kd}$ force as an optimal balance between producing accurately measurable deficits in locomotor function and a reduction in the severity of bladder complications.

Surgical procedures. Sterile surgical techniques and methods were used throughout the entire surgical procedure in a designated surgical room. Twenty-eight BUB C1q KO and twenty-three BUB WT mice weighing between 28 and $35 \mathrm{~g}$ were anesthetized with Avertin $(0.5 \mathrm{ml} / 20 \mathrm{~g}$ tribromo-ethanol). Following a midline incision on the skin and after the muscle was separated exposing a portion of the vertebral column, thoracic vertebrae 9 (T9) was exposed by laminectomy. Mice received a 40 $\mathrm{kd}$ contusion injury at T9 with the Infinite Horizon Impactor (Precision Systems and Instrumentation [PSI], Lexington, KY). After the contusion injury, a small piece of sterile surgical gel-foam was placed over the laminectomy, the musculature was sutured and skin closed using metal wound clips. Mice were then given a subcutaneous dose of buprenorphine $(0.5 \mathrm{mg} / \mathrm{kg})$, baytril $(2.5 \mathrm{mg} / \mathrm{kg})$ and saline $(1 \mathrm{cc})$. Singly housed, SCI mice were placed on water-jacketed heating pads overnight to maintain constant body temperature. The following day, mice were returned to their normal housing room. Manual bladder care was performed three times per day throughout the duration of the study. All animals were maintained on cipro antibiotics once per day and saline until killing.

Hemolytic complement assay. The hemolytic complement assay (CH50) assay or total complement assay measures the ability of classical pathway activated membrane attack complex (MAC) to lyse sheep red blood cells (RBCs) with a subagglutinizing concentration of antibody. The percentage of erythrocyte lysis of given dilution of the serum tested directly reflects the percentage of total complement activity (Dodds and Sim, 1997). Before perfusion, $0.5-1 \mathrm{ml}$ of blood was withdrawn by cardiac puncture and collected in borosilicate $12 \times 75 \mathrm{~mm}$ glass tubes and allowed to clot for an initial $5 \mathrm{~min}$ at room temperature (RT) and then on ice for $45 \mathrm{~min}$. After centrifugation of the sample at $2000 \mathrm{rpm}$ for $15 \mathrm{~min}$, serum was recovered and stored at $-80^{\circ} \mathrm{C}$ until assayed for complement activity. Total complement activity was tested as previously described (Dodds and Sim, 1997) by adding $50 \mu \mathrm{l}\left(50 \times 10^{8} / \mathrm{ml}\right)$ of antibody sensitized erythrocytes (EA), prepared by incubation of sheep erythrocytes (E) (Colorado Serum Company) with rabbit anti-sheep red blood cells antibodies (A's, $1 / 75 \mathrm{IgG}$ ), to serial dilution of the serum $(1 / 15,1 / 30$, $1 / 60,1 / 00)$ diluted in $250 \mu \mathrm{l}$ of Gelatin Veronal Buffer $\left(\mathrm{GVB}^{2+}\right)$ on ice. All reaction mixtures were prepared in borosilicate glass tubes. The samples were incubated at $37^{\circ} \mathrm{C}$ for $1 \mathrm{~h}$ and then centrifuged at $3000 \mathrm{rpm}$ for 3 min to pellet un-lysed erythrocytes. Supernatants were split in duplicate in 96 well plates, and the optical density (OD) was measured at 405 $\mathrm{nm}$. Percentage of total complement lytic activity, correspondent to the percentage of EA's lysis was calculated using the following formula: $\left[(\right.$ sample OD) - (buffer control OD) $] /\left[\left(\mathrm{H}_{2} \mathrm{O}\right.\right.$ lysis OD) - (buffer control OD)]. Units of serum required to lyse $50 \%$ of EA were calculated for all samples using a logarithmic regression analysis as previously described (Dodds and Sim, 1997). Serum samples were analyzed from a minimum of $4-5$ animals per group.

$\mathrm{C} 3 \mathrm{H} 50$ and $\mathrm{C} 5 \mathrm{H} 50$ assay. $\mathrm{C} 3 \mathrm{H} 50$ and $\mathrm{C} 5 \mathrm{H} 50$ assays were performed according to the manufacturer's recommendations (Quidel) with minimal modifications. Briefly, for the C3H50, $60 \mu \mathrm{l}$ of EA's $\left(2.5 \times 10^{8} / \mathrm{ml}\right)$ were added to serial dilutions of mice serum $(1 / 100,1 / 200,1 / 400,1 / 800$, $1 / 1600)$ in $177.5 \mu \mathrm{l}$ of $\mathrm{GVB}^{2+}$. The mixture was then incubated with C3 depleted serum (C3D, 1:100, Quidel) for $1 \mathrm{~h}$ at $37^{\circ} \mathrm{C}$. The $\mathrm{C} 5 \mathrm{H} 50$ assay was performed by adding $100 \mu \mathrm{l}$ of EA's $\left(1.5 \times 10^{8} / \mathrm{ml}\right)$ and C5 depleted serum (C5D, 1:25, Quidel) to serial dilutions of mice serum in $\mathrm{GVB}^{2+}$ buffer $(1 / 00,1 / 300,1 / 600,1 / 1200,1 / 2400)$ for $30 \mathrm{~min}$ at $37^{\circ} \mathrm{C}$. After centrifugation at $3000 \mathrm{rpm}$ for $3 \mathrm{~min}$, supernatants were split in duplicate in 96 well plates, and the OD was measured at $405 \mathrm{~nm}$. Units of serum required to lyse $50 \%$ of EA were calculated for all samples using a logarithmic regression analysis as previously described (Dodds and Sim, 1997). Results of C3H50 and C5H50 values (unit of serum $/ \mathrm{ml}$ required to lyse $50 \%$ of sheep erythrocytes) were expressed as a percentage of hemolytic activity relative to BUB male controls, which had the highest percentage of total complement activity. Serum samples were analyzed from a minimum of 7-9 animals per group.

Basso Mouse Scale open field task. The ten-point Basso Mouse Scale (BMS) scale is a sensitive, valid and reliable nonlinear scale to measure locomotor recovery in mice after SCI (Basso et al., 2006). The sensitivity of the BMS scale is sufficient to distinguish gross locomotor recovery in spinal cord injured mice. This task has the advantage of spanning the range from complete paralysis to normal locomotion. A BMS score of 
zero indicates the animal had complete hindlimb paralysis, whereas a BMS score of 9 indicates the animal had no locomotor deficits (uninjured animal). Before spinal cord injury, mice were exposed to the testing environment for a period of $7 \mathrm{~d}$. Spontaneous locomotor recovery was assessed and scored at 1, 2, 7, 14, 21 and $28 \mathrm{~d}$ post-SCI by observers blinded to the experimental groups.

CatWalk gait assessment. CatWalk was used to assess locomotor gait dynamics. This method of gait analysis allows for easy quantification of a large number of gait parameters during walkway crossings (Hamers et al., 2001). Animals were allowed to walk down a glass walkway $4.5 \mathrm{~cm}$ wide. The glass $(109 \times 15 \times 0.6 \mathrm{~cm})$ is illuminated along the long edge by an encased fluorescent tube. The light that enters the glass is internally reflected when bordered by air, thereby acting as an optical fiber. As animals crossed the walkway, light was reflected off the animal's paws producing a series of footprint images. These footprint images were recorded by a video camera that is located underneath the walkway. Mice were tested on CatWalk before SCI and at the end of the study, $28 \mathrm{~d}$. Data analysis consisted of assigning a label (left-fore, left-hind or right-fore, right-hind) to the animal's paw prints as it crossed the walkway using CatWalk 6.13 software (designed and written by Frank P. T. Hamers). Individuals that analyzed the data were blinded to the animal's genotype and identity of the groups. To obtain meaningful and accurate locomotor data, the following criteria concerning walkway crossings were used: (1) the animal needed to walk across the walkway uninterrupted and at a consistent pace, (2) a minimum of three crossings per animal were required and the resulting data were averaged for statistical analysis.

von Frey testing. Hindlimb sensory function was assessed by von Frey filament testing. Briefly, mice were placed inside a transparent chamber sitting atop an elevated wire mesh platform and acclimated to the testing chamber for $2 \mathrm{~h}$ over a period of $2 \mathrm{~d}$ post-injury. On the third day, von Frey filament testing began when the animals showed minimal signs of grooming and exploratory behavior. A modified version of the ascending-descending method from Chaplan et al. (1994) was used for the assessment of withdrawal threshold response. Using our method, the hind paw was touched starting with the von Frey hair (Stoelting) with the lowest force $(0.008 \mathrm{~g})$ and held perpendicular to the plantar surface of the hind paw for 5-7 s. Filaments of increasing magnitude were then applied until paw withdrawal was obtained. A positive response was defined by a sharp paw withdrawal or licking/biting of the hind paw. The filament force producing a positive response was defined as the animal's response threshold. The response threshold was then confirmed using the following methods: (1) the filament force immediately below the response threshold was applied to the hind paw to insure the absence of a paw withdrawal; (2) the filament force immediately above the response threshold was applied to the hind paw to confirm paw withdrawal with this filament; (3) once the animal's response threshold was confirmed, the filament resulting in paw withdrawal was verified by testing the same paw for three consecutive trials, allowing $1 \mathrm{~min}$ of recovery between successive trials. Using this method, the filament producing the response threshold resulted in $100 \%$ paw withdrawal. All animals were tested on one hind paw before testing the contralateral paw. We found no significant differences between the threshold responses of each hind paw within the same animal, and thus, the average threshold response of both hind paws is reported. Von Frey testing was performed by an individual blinded to the animal's genotype and identity of the groups.

Tissue collection. Mice were killed with a lethal dose of sodium pentobarbital $(0.4 \mathrm{ml}) 28 \mathrm{~d}$ post-injury and perfused via the aorta with cold $4 \%$ paraformaldehyde. Spinal cord segments containing the injury epicenter were dissected by T6-T12 spinal roots, sunk in 20\% sucrose/4\% paraformaldehyde overnight at $4^{\circ} \mathrm{C}$, flash frozen in isopentane (2methlybutane) at $-56^{\circ} \mathrm{C}$ and then stored at $-80^{\circ} \mathrm{C}$ until sectioned for immunohistochemistry.

Immunohistochemistry. Parasagittal sections $(30 \mu \mathrm{m})$ were cut on a sliding microtome, collected in 48 well plates containing PBS $+0.05 \%$ sodium azide and stored at $4^{\circ} \mathrm{C}$ until needed. For stereological analysis, a series of parallel sections from the entire injury segment of the spinal cord (T6-T12) were processed as described below. Spinal cord sections were mounted on gelatinized (Sigma-Aldrich) Fisher brand slides and placed on a slide warmer for $30 \mathrm{~min}$ at $55^{\circ} \mathrm{C}$. Every fifth section was processed for
Table 1. Intra-animal variation in stereological analysis

\begin{tabular}{lll}
\hline & \multicolumn{2}{l}{ Average mean coefficient of error } \\
\cline { 2 - 3 } Immunohistochemical parameter & WT & C1q K0 \\
\hline Fibronectin & 0.024 & 0.040 \\
Central core lesion volume & 0.025 & 0.036 \\
GFAP scar volume & 0.020 & 0.027 \\
F4/80-positive cells & 0.073 & 0.073 \\
\hline
\end{tabular}

fibronectin (1/300 dilution of $0.6 \mathrm{mg} / \mathrm{ml}$ supplied concentration; Sigma, F3648), glial fibrillary acidic protein (GFAP) (1/20,000 dilution of 2.4 $\mathrm{mg} / \mathrm{ml}$ supplied concentration; Dako, Z0334), and F4/80 (1/25 dilution of $1.0 \mathrm{mg} / \mathrm{ml}$ supplied concentration; Serotec, MCA497R) and visualized with diaminobenzidine (DAB) (Vector Laboratories). Control sections were incubated without the primary antibody to test for antibody specificity.

Stereological quantification of tissue damage, glial scar and macrophages/ microglia. Unbiased stereological analyses were performed on a series of parasagittal sections (11-14 sections per animal) spaced $150 \mu \mathrm{m}$ apart using the StereoInvestigator system (Microbright Field, version 7.003 software). All analyses were performed with an Olympus BX51 model microscope with a motorized stage under identical light microscopy conditions for each of the parameters measured. Starting sections were chosen randomly and every fifth section throughout the entire injury segment was analyzed (defined by anatomical T6-T12 spinal roots). The grid sizes used in the analyses were determined empirically to arrive at a coefficient of error (CE) that was $<0.10$ for all animals examined (Table 1). All stereological analyses were performed by individuals blinded to the animal's genotype and identity of the groups.

The Cavalieri estimator was used to quantify: total cord volume (T6T12), fibronectin volume, central core lesion volume, and GFAP area. The fibronectin lesion volume and the central core lesion volume were quantified using two separate series of sections stained with fibronectin or GFAP respectively. Cavalieri sampling used a series of graphic overlays for probe measurements that were superimposed over the specimen. The total cord volume (T6-T12) and fibronectin volume were determined simultaneously by first drawing a contour around the entire area of each section followed by randomly placing a grid $(50 \mu \mathrm{m} \times 50 \mu \mathrm{m})$ on the section and counting the number of points that fell on both the section and on the area that was positively stained for fibronectin. This analysis was performed using a $10 \times$ objective. A similar methodology was used to determine the central core lesion volume and GFAP area except that the grid size to determine the GFAP area was $150 \mu \mathrm{m} \times 150 \mu \mathrm{m}$ and the analysis was performed with a $4 \times$ objective. The widespread expression of GFAP in the spinal cord makes it very difficult to accurately distinguish the GFAP scar from normal GFAP immunoreactivity in spinal cord sections that lack a discernible injury epicenter. Accordingly, stereological analysis of GFAP scar was performed in only those sections that contained the injury epicenter. Therefore, the GFAP scar is reported as a measure of area and not volume. The GFAP-immunopositive area was determined by subtracting the central core lesion area (defined as the area surrounded by GFAP that was devoid of GFAP staining) from the GFAP-positively stained area. The total injured cord volume, fibronectin lesion volume and central core volume was calculated using the Cavalieri method (Howard and Reed, 1998; Guo and Ward, 2006) for volume (V):

$$
V=A_{p} m t \times\left[\sum_{i=1}^{n} P_{i}\right]
$$

where $A_{p}=$ area associated with a point, $m=$ section periodicity, $t=$ mean section thickness, and $P_{i}=$ total points counted.

The optical fractionator was used to quantify F4/80-positive cells in parasagittal tissue sections immunolabeled with F4/80 antibody and counterstained with methyl green. The following criteria were used to determine F4/80-positive cells: the cell had to be immunopositive for F4/80 and contain a prominent nucleus visualized by methyl green. Only cells that satisfied this criterion, that came into focus during the scanning 
of the tissue from top to bottom and that fell within the boundary or inclusion lines of the counting frame were counted. The quantification of F4/80-positive cells was performed with oil immersion $60 \times$ objective using the following sampling parameters: (1) a counting frame area of $2500 \mu \mathrm{m}^{2}$, (2) a dissector height of $8 \mu \mathrm{m}$, (3) an upper guard zone of 2 $\mu \mathrm{m}$. The estimated total $\mathrm{F} 4 / 80$ positive cells were calculated using the optical fractionator method $(N)$ :

$$
N=\left[\sum Q^{-}\right] \times \frac{t}{h} \times \frac{1}{\mathrm{asf}} \times \frac{1}{\mathrm{ssf}},
$$

where $Q$ is the total point counted, $t=$ mean section thickness, $h=$ optical dissector height, asf $=$ area sampling fraction, and ssf $=$ slice sampling fraction.

Flow cytometry. To assess the cellular inflammatory response in the spinal cord after SCI, dissected spinal cord tissue (vertebral level T8T10) was diced in HBSS, collected, and transferred to DMEM (Invitrogen) [containing trypsin $(0.5 \mathrm{mg} / \mathrm{ml})$ and collagenase $(1 \mathrm{mg} / \mathrm{ml})$ ], for 20 min at $37^{\circ} \mathrm{C}$. Cell pellets were collected by centrifugation $(6 \mathrm{~min}$ at $100 \times$ $g$ ) and debris was further separated from cells by overlaying cell suspension on four different layers of OptiPrep gradient (Fisher) followed by centrifugation (1900 RPM for $15 \mathrm{~min}$ at $20^{\circ} \mathrm{C}$ ) (Nguyen et al., 2008). Red blood cells (RBCs) were lysed with ammonium chloride solution and the cell suspension was incubated for 30 min with normal rabbit serum. Subsequently, the cell suspension was incubated for $1 \mathrm{~h}$ with anti-mouse neutrophil antibody (Serotec: 1/500) or anti-mouse F4/80 (Macrophage antibody: Serotec: 1/100). After several washes, cells were incubated for $1 \mathrm{~h}$ in solution of Alexa-488 (1:500) or Cy5 conjugated IgGs (1:500); and $30 \mathrm{~min}$ in solution of propidium iodide (1:100; Invitrogen) to label dead cells before fluorescence-activated cell sorting (FACS) on a Calibur (Becton-Dickinson) flow cytometer. Cell viability was typically $>95 \%$ and all FACS gates were set using unlabeled cells. Animals from two separate experiments were combined for the microglia/macrophage (F4/ 80) FACS data.

Statistical methods. Statistical analyses were performed using GraphPad Prism (version 5). Comparisons between groups on the BMS locomotor rating scale were performed using repeated measures ANOVA with post hoc Bonferroni Dunn. CH50 data were analyzed by either twoway ANOVA followed by linear contrast tests with Bonferroni Dunn corrections or by two-way repeated measures ANOVA followed by Bonferroni's multiple comparison tests, where appropriate. $\mathrm{C} 3 \mathrm{H} 50$ and C5H50 data were analyzed by one-way ANOVA followed by Bonferroni's multiple comparison tests. Student's $t$ tests were used for group comparisons of data obtained from CatWalk gait analysis, von Frey filament testing, stereological analyses, and flow cytometric analyses (FACS). Correlation results were analyzed with Pearson linear regression. Values of $p \leq 0.05$ were considered significant. All data are expressed as mean \pm SEM.

\section{Results \\ Strain and gender differences in total hemolytic complement activity}

Studies by Ong et al. (1989) have shown that total complement activity in mice is strain and sex dependent. To confirm these findings, total classical complement assays ( $\mathrm{CH} 50)$ were performed in naive animals matched by age and weight. ANOVA comparisons were conducted at the $1 / 15$ dilution, and revealed significant effects for strain $(F=290.573, p<0.0001)$ and gender $(F=291.519, p<0.0001)$. Serum from BUB males at $1 / 15$ dilution lysed an average of $93.2 \%$ of erythrocytes, while at the same dilution, serum from BL/6 males lysed only $16.2 \%$ of erythrocytes (linear contrast with Bonferroni correction vs BUB males $p<0.0005)$. Similar to BL/ 6 males, BUB females exhibited $10.5 \%$ erythrocyte hemolysis (linear contrast with Bonferroni correction vs BUB males $p<0.0005)$. In summary, naive BUB male mice exhibited significantly greater classical complement activity compared with BUB female, or BL/6 male mice (Fig. 1A).

\section{Strain and gender differences in C5 hemolytic activity}

It has been previously suggested that complement protein $\mathrm{C} 3$ levels are elevated in BUB mice compared with BL/6 mice (Ong and Mattes, 1989; Ong et al., 1992). However, a recent study showed that C3 protein levels and C3 activity as assessed by deposition of $\mathrm{C} 3 \mathrm{~b}$ on bacteria are not different between BUB and BL/6 mice (Osmers et al., 2006). The deposition of C3b marks bacterium for efficient recognition and phagocytosis by phagocytic cells expressing C3b receptors. This however, does not necessarily indicate formation of a stable C5 convertase (C4b,2b,3b), or subsequent assembly of the membrane attack complex (C5b9), the target measured in $\mathrm{CH} 50$ assays. To investigate the contribution of C3 and C5, respectively, to total hemolytic activity, naive animals from strains/genders that exhibited detectable baseline complement activity (Fig. $1 A$ ) were assayed using standard $\mathrm{C} 3 \mathrm{H} 50$ and $\mathrm{C} 5 \mathrm{H} 50$ substitution assays. All data were normalized and expressed as a percentage relative to male BUB mice because BUB male mice showed the greatest total complement activity (Fig. $1 A$ ) compared with the other groups. There was a significant group effect for $\mathrm{C} 3$ activity as measured by $\mathrm{C} 3 \mathrm{H} 50$ assay (one-way ANOVA; $F=4.913, p=0.0184$ ). Post hoc tests revealed a significant group difference only between BUB female and BL/6 male mice (Bonferroni's multiple comparison, $p<$ $0.05)$, suggesting a trend for gender but not strain differences in C3 (Fig. $1 B$ ). In parallel, C5H50 assays showed a significant group effect for C5 activity (one-way ANOVA; $F=32.89$, $p<$ 0.0001). Post hoc tests revealed that BUB male mice exhibited significantly greater $\mathrm{C} 5$ activity than either BL/6 male or BUB female mice (Bonferroni's multiple comparison, $p<0.05$ ), suggesting that differences in C5 activity may contribute to differences in total complement activity observed between BUB and BL/6 mice (Fig. 1C).

\section{Total hemolytic complement activation after SCI}

Although we have previously demonstrated that immunoreactivity for complement components, including the C5b-9 neoepitope, is present beginning at $24 \mathrm{~h}$ and extending through $42 \mathrm{~d}$ post-SCI (Anderson et al., 2004), there is no direct evidence of systemic complement activation after SCI in the literature. We, therefore, tested serum for total hemolytic complement activity by $\mathrm{CH} 50$ in naive and injured mice $24 \mathrm{~h}$ post-SCI. Only naive animals from strains/genders that exhibited detectable baseline complement activity (Fig. $1 A$ ) were assayed using standard dilution $\mathrm{CH} 50$ (Fig. 1D). All data were then normalized and expressed as a percentage relative to naive male BUB mice because naive male BUB mice showed the greatest complement activity. Comparison of naive and SCI animals showed a significant main effect for both strain, $F_{(2,12)}=65.76, p<0.0001$, and time, $F_{(1,12)}$ $=6.16, p<0.05$ (two-way repeated measures ANOVA) (Fig. $1 E)$. Post hoc tests revealed significant complement consumption in naive versus SCI male BUB mice (Bonferroni's multiple comparison, $p<0.01$ ); however, no significant difference was detected between naive and SCI male BL/6 mice or between naive and SCI female BUB mice (Bonferroni's multiple comparison, $p>0.05$ ) (Fig. $1 E$ ). In summary, these data suggest that only BUB males exhibited measurable hemolytic complement activation in the acute period $(24 \mathrm{~h})$ post-SCI.

\section{BUB C1q KO mice lack total classical complement activity}

Given the significantly greater levels of total classical complement activity in BUB versus $\mathrm{BL} / 6$ mice, $\mathrm{Clq} \mathrm{KO}$ mice on a mixed $\mathrm{BL} / 6$ background were backcrossed onto the BUB strain to generate both BUB WT and BUB C1q KO mice. The resulting male BUB 
WT progeny exhibited complete functional complement activity, whereas male BUB C1q KO mice showed a complete loss of total classical complement activity (Fig. $1 F)$.

\section{Effect of C1q on recovery of locomotor function}

Locomotor recovery was assessed using the BMS open-field rating scale beginning on day 1 , day 7 , and on a weekly basis thereafter (Fig. 2). As noted in the injury paradigm description under Materials and Methods, to minimize bladder complications and mortality, both BUB WT and BUB C1q KO mice received a mild contusion injury; accordingly, the BMS data demonstrated a high degree of spontaneous recovery for both BUB WT and BUB $\mathrm{C} 1 \mathrm{q} \mathrm{KO}$ mice. At the end of the study, $28 \mathrm{~d}$ post-injury, BUB WT mice attained a BMS score of $6.7 \pm 0.64$, whereas BUB C1q KO mice attained a BMS score of $6.9 \pm 0.33$. A BMS score of 7 indicates the animal had frequent to consistent stepping and was mostly coordinated. Locomotor recovery on the BMS scale was not significantly different between groups over time (two-way repeated-measures ANOVA, $p>0.05$ ). While repeated-measures ANOVA is the most appropriate analysis for this data set as a whole, complement might be predicted to exert a changing influence on the injury environment over time, contributing to both degenerative and regenerative/ repair events. We therefore also compared BUB C1q KO and BUB WT mice at individual time points of BMS assessment. BUB C1q KO mice showed improved recovery compared with WT mice 2 d postinjury (Student's $t$ test, $p<0.05$ ); BUB $\mathrm{Clq} \mathrm{KO}$ mice demonstrated plantar placement (mean BMS score of $2.86 \pm 0.33$ ); whereas, BUB WT mice displayed extensive ankle movements (mean BMS score of $1.9 \pm 0.39$ ).

As a result of the injury paradigm used in this study, we predicted that differences between these groups would be limited to the fine details of locomotion. The most accurate test to assess the fine details of locomotion after SCI is kinematic CatWalk gait analysis (Koopmans et al., 2005; Liebscher et al., 2005; Kigerl et al., 2006; Cao et al., 2008). Locomotor recovery after mid-thoracic contusion-induced SCI has been shown to be associated with an increase in percent regularity index (\%RI) an increase in hindlimb swing duration (msec) and a decrease in hindlimb swing speed (m/s) (Hamers et al., 2001). BUB C1q KO mice exhibited an increase in \%RI compared with BUB WT mice $(90.3 \pm 1.9 \%$ vs $84.5 \pm 2.4 \%$, respectively, Fig. $3 D$, Student's $t$ test, $p<0.05)$ demonstrating that BUB C1q KO displayed greater one-to-one correspondence between the forelimbs and hindlimbs. In addition, BUB C1q KO mice showed a signif-
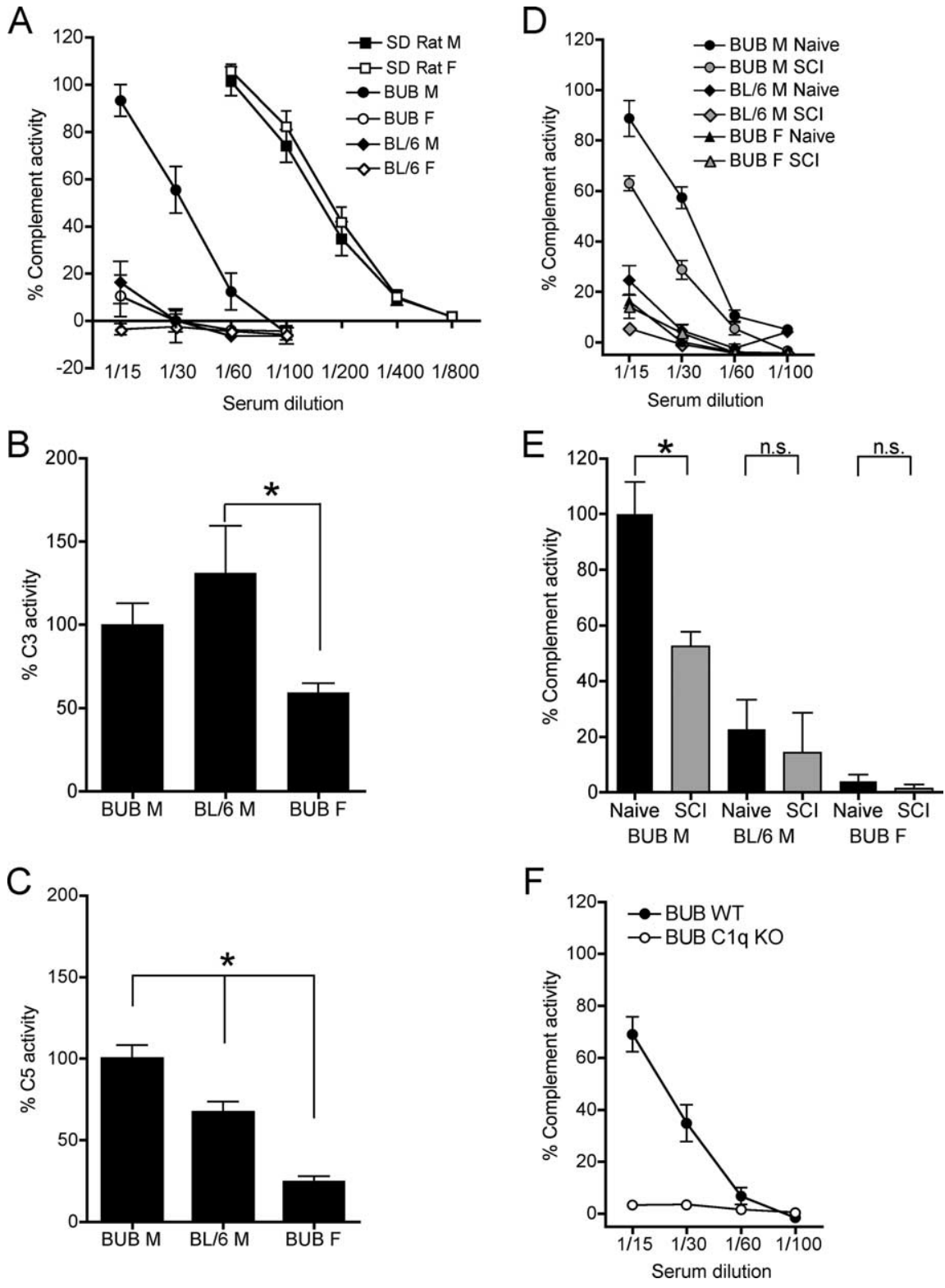

Figure 1. Hemolytic analyses of complement activity in serum. $A$, Male (M) BUB $(n=5)$ mice exhibited significantly greater total complement activity in serum compared with female (F) BUB $(n=5)$ and compared with either BL/6 M $(n=5)$ or BL/6 F $(n=5)$ mice but less than Sprague Dawley rats $(\mathrm{M}, n=4, \mathrm{~F}, n=4)$ (ANOVA: linear contrast with Bonferroni corrections, ${ }^{*} p<$ 0.0005). B, BL/6 M $(n=7)$ showed significantly greater C3 activity compared with BUB F $(n=9)$ mice (ANOVA, Bonferrroni's multiple comparison, $\left.{ }^{*} p<0.05\right)$. C, BUB M $(n=8)$ mice showed significantly greater $(5$ activity compared with BL/6 M $(n=7)$ and BUB F $(n=7)$ mice (ANOVA, Bonferrroni's multiple comparison, $\left.{ }^{*} p<0.05\right)$. D, CH50 assay dilution curves of naive and SCI mice. $\boldsymbol{E}$, Logarithmic regression analysis of naive and $\mathrm{SCl}$ animals revealed significantly decreased complement activity in $\mathrm{SCI}(n=$ 5) versus naive $(n=5)$ male BUB mice, indicating complement cascade activation (repeated measures ANOVA, Bonferroni's multiple comparison $\left.{ }^{*} p<0.05\right)$. However, no significant differences were noted between naive and $\mathrm{SCl}$ animals within the other groups. $\boldsymbol{F}, \mathrm{C} 1 q \mathrm{KO}(n=4)$ mice backcrossed onto the BUB background showed a complete loss of total classical complement activity compared with WT $(n=4)$ littermates. Data points represent group means \pm SEM.

icant increase in the average swing duration of the hindlimbs compared with WT mice ( $58 \pm 3 \mathrm{~ms}$ vs $52 \pm 2 \mathrm{~ms}$, respectively, Fig. $3 E$, Student's $t$ test, $p<0.05)$. Furthermore, BUB C1q KO mice showed a significant reduction in the average swing speed of the hindlimbs compared with BUB WT mice $(0.85 \mathrm{~m} / \mathrm{s} \pm 0.02 \mathrm{vs}$ $0.93 \mathrm{~m} / \mathrm{s} \pm 0.03$, respectively, Fig. $3 F$, Student's $t$ test, $p<0.05)$. Additionally, to confirm that the post-injury effects were not inherent to differences in gait dynamics between the groups, we tested a separate group of naive animals on CatWalk. As expected, no significant differences were noted between groups pre- 


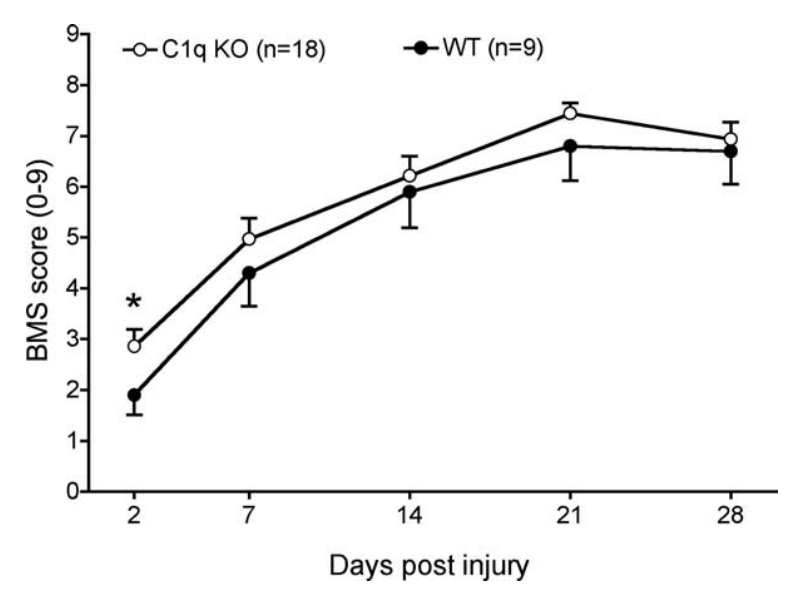

Figure 2. BMS recovery curves illustrate the extent of gross functional locomotor recovery in C1q KO and WT mice following a mild contusion injury. Repeated measures ANOVA analysis showed that locomotor recovery was not significantly different between groups over time $(p>0.05)$. Additional comparisons revealed that C1q KO showed improved recovery compared with WT mice $2 \mathrm{~d}$ post-injury (Student's $t$ test, ${ }^{*} p<0.05$ ). Data points represent group means \pm SEM.

injury (Fig. 3A-C) (Student's $t$ test, $p>0.05$ ). It is important to note that no significant differences were detected in the number of seconds that it took the animals to cross the walkway (as differences in the duration of walkway crossing between the groups may affect coordination, swing duration and swing speed). Together, the observed significant improvements in the fine details of locomotion in BUB C1q KO mice suggest that the classical complement pathway plays a detrimental role to locomotor recovery after SCI.

\section{Effect of C1q on threshold sensitivity in von Frey filament testing}

A subset of BUB C1q KO mice showed signs of excessive hind paw grooming during the last week of behavioral testing. Contusion SCI is associated with damage to ascending sensory as well as descending motor pathways, resulting in loss of sensation and proprioception in addition to loss of motor function. Additionally, SCI can lead to chronic central pain (CCP) syndromes both in the clinical situation and in rodent models (Christensen et al., 1996; Mills et al., 2001). Distinguishing between recovery of sensation and the evolution of allodynia (heightened sensitivity to normally non-noxious stimuli) after SCI can be difficult without extensive testing. However, we sought to determine whether BUB $\mathrm{Clq} \mathrm{KO}$ mice exhibited altered sensation in response to mechanical stimulation of the plantar surface of the hindlimb using threshold testing with von Frey filaments. This method measures the threshold or force at which a paw withdrawal response is elicited after stimulation of the globular region of the plantar paw surface. The force required to elicit a hind paw withdrawal in SCI BUB C1q KO mice $(0.91 \pm 0.21 \mathrm{~g})$ was significantly lower in magnitude than the force required in eliciting a hind paw withdrawal in SCI BUB WT mice (1.32 $\pm 0.08 \mathrm{~g}$ ) (Fig. $4 B$ ) (Student's $t$ test, $p<0.05$ ). To investigate whether the observed difference between groups could be inherent to the BUB C1q KO strain and independent of SCI, we tested the threshold to withdrawal in a separate group of naive BUB WT and BUB C1q KO mice using the same methods. There was no significant difference in the magnitude of the force necessary to elicit a hind paw withdrawal between the groups before injury (Fig. $4 A$ ) (Student's $t$ test, $p>$ $0.05)$, suggesting that BUB C1q KO and BUB WT mice developed a different pattern of responsiveness to mechanical stimulation post-injury.

\section{Effect of C1q on lesion volume, tissue sparing, and the glial scar}

Contusion-induced SCI in mice causes extensive tissue damage that spreads rostral and caudal to the injury site, while the central region of the lesion becomes filled with a dense fibronectin rich matrix (Ma et al., 2001). Additionally, a prominent pathological feature of SCI is astrogliosis and the development of an astrocytic glial scar surrounding the injury epicenter. Complement has been shown to cause tissue damage in animal models of disease, including arthritis (Goodfellow et al., 1997; Mizuno et al., 2000), experimental allergic encephalomyelitis (Piddlesden et al., 1994; Nataf et al., 2000; Niculescu et al., 2003; Weerth et al., 2003; Boos et al., 2004) and experimental autoimmune myasthenia gravis (Piddlesden et al., 1996). To determine whether the classical complement pathway affects fibronectin lesion volume, central core lesion volume, or astrocytic glial scar (GFAP) volume, spinal cord tissue obtained $28 \mathrm{~d}$ post-injury was immunolabeled for fibronectin and GFAP, respectively, as described under Materials and Methods.

Both BUB C1q KO and BUB WT mice showed fibronectinpositive labeling that was restricted to the injury epicenter and extensive GFAP immunoreactivity that extended rostral and caudal to the injury site (Fig. $5 C, D$ ). No positive immunolabeling was noted in spinal cord tissue in which the primary antibody was omitted during the staining procedure.

Unbiased stereological analysis revealed that BUB $\mathrm{Clq} \mathrm{KO}$ mice showed a significant reduction in the fibronectin volume compared with BUB WT mice (Figs. $5 A, B, 6 A ; 0.048 \mathrm{~mm}^{3} \pm$ 0.013 and $0.085 \mathrm{~mm}^{3} \pm 0.015$, respectively, Student's $t$ test, $p<$ $0.05)$. Three-dimensional (3-D) reconstructions of representative injured spinal cord segments were generated to illustrate the reduced fibronectin lesion volume (red shading) in BUB C1q KO mice compared with WT mice (Fig. 5E,F). Furthermore, BUB $\mathrm{Clq} \mathrm{KO}$ mice showed a significant reduction in the central core lesion size compared with BUB WT mice (Figs. $5 C, D, 6 B ; 0.045$ $\mathrm{mm}^{3} \pm 0.010$ vs $0.084 \mathrm{~mm}^{3} \pm 0.014$, respectively, Student's $t$ test, $p<0.05)$. The central lesion was defined as the area devoid of GFAP-positive labeling. Correlational analysis of fibronectin lesion volume and central core lesion volume revealed a strong positive correlation between these two separate quantitative measures of lesion volume (Fig. 7A) (Pearson: fibronectin lesion volume vs central core lesion volume, $r=0.839, p<0.0001)$. Accordingly, quantification of spared tissue in sections immunolabeled with fibronectin revealed that the percentage of spared tissue in BUB C1q $\mathrm{KO}$ mice was significantly increased compared with BUB WT mice (Fig. 6C) (98.65 $\pm 0.36 \%$ vs $97.8 \pm$ $0.28 \%$ respectively, Student's $t$ test, $p<0.05$ ). In contrast to the changes observed in fibronectin volume, central core lesion volume and spared tissue volume; there was no difference in GFAP area between BUB C1q KO mice and BUB WT mice (Figs. $5 C, D$, 6D) $\left(5.35 \mathrm{~mm}^{2} \pm 0.986,5.79 \mathrm{~mm}^{2} \pm 0.723\right.$, respectively, Student's $t$ test, $p>0.05)$. Together, these data suggest that the classical complement pathway contributes to tissue damage but not glial scar formation following a moderate contusion injury.

\section{Correlative analyses}

In the present study, we report that $\mathrm{BUB} \mathrm{Clq} \mathrm{KO}$ mice demonstrated significant improvements in the fine details of gait and reduced lesion volume after contusion SCI. Although CatWalk is a sensitive and quantitative method of gait analysis following SCI, 
there are no reports in the literature that correlate behavioral improvements on CatWalk with improvements on histological outcome following SCI. We report for the first time correlative analysis of CatWalk gait dynamics versus stereological assessment of fibronectin lesion volume. To investigate the relationship between lesion volume and behavioral recovery for BUB C1q KO mice, we performed regression analyses for fibronectin lesion volume and the following gait parameters: (1) \%RI, (2) swing duration, (3) swing speed. Given the increased \%RI, the increased swing duration and the decreased swing speed observed in BUB C1q $\mathrm{KO}$ mice, we predicted a negative correlation between fibronectin lesion volume versus \%RI and swing duration, whereas, we predicted a positive correlation between fibronectin lesion volume versus swing speed. As predicted, linear regression analyses for BUB $\mathrm{Clq} \mathrm{KO}$ revealed a significant negative correlation between fibronectin lesion volume versus \%RI and swing duration (Fig. $7 \mathrm{~B}, \mathrm{C}$ ) (Pearson: fibronectin lesion volume vs $\%$ RI, $r=-0.62, p=0.049$; fibronectin lesion volume vs swing speed, $r=-0.66, p=0.038$ ). Additionally, regression analysis for $\mathrm{BUB} \mathrm{Clq} \mathrm{KO}$ mice revealed a trend for a positive correlation for fibronectin lesion volume versus swing speed (Fig. 7D) (Pearson, $r=0.59 p=$ $0.062)$. In contrast, linear regression analyses for BUB WT mice did not demonstrate significant correlations between fibronectin lesion volume versus \%RI, swing duration and swing speed (data not shown). Together, these data demonstrate that the improved behavioral recovery observed in BUB C1q $\mathrm{KO}$ mice is directly related to a decrease in lesion volume. These results suggest that reducing lesion volume could be instrumental to recovery of locomotor function following a mild thoracic contusion injury.

\section{Effect of C1q on inflammatory cell infiltration after SCI}

Complement plays a significant role in recruiting and activating the cellular inflammatory response as result of infectious agents and acute trauma (Mulligan et al., 1992). Infiltration of bloodborne leukocytes into the spinal cord after SCI is well documented in the literature (Hamada et al., 1996; Popovich et al., 1999; Gonzalez et al., 2003; Saville et al., 2004); however, it is currently unknown whether the classical complement pathway contributes to the recruitment of inflammatory cells after SCI. We sought to investigate the acute inflammatory cell response by FACS analysis.

To parallel the behavioral studies, animals received a $40 \mathrm{kd}$ contusion injury and spinal cords were processed for FACS analysis as described in the Materials and Methods section. We hypothesized that BUB C1q KO mice would show reduced infiltration of neutrophils and macrophages. There was no significant difference in the percentage of neutrophils detected by FACS analysis between BUB WT $(3.1 \pm 1.9 \%)$ and BUB C1q KO (1.8 \pm $0.5 \%$ ) mice (Fig. $8 A$ ) (Student's $t$ test, $p>0.05$ ) 24 h post-SCI. Moreover, there was no significant difference in the percentage of
Pre-injury
B

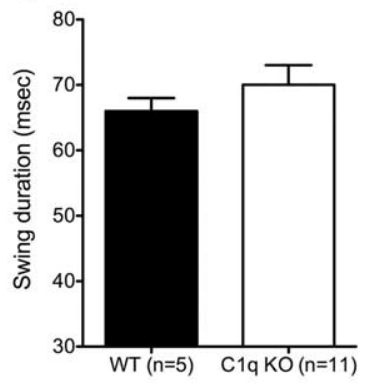

$28 \mathrm{dpi}$

E

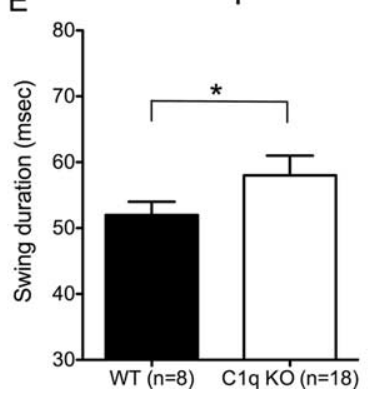

C

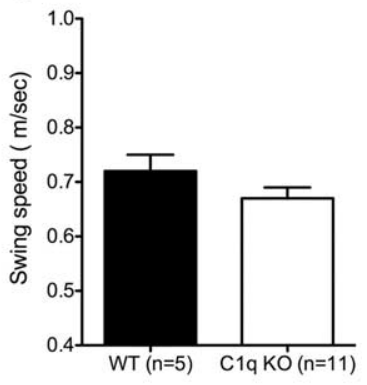

$\mathrm{F}$

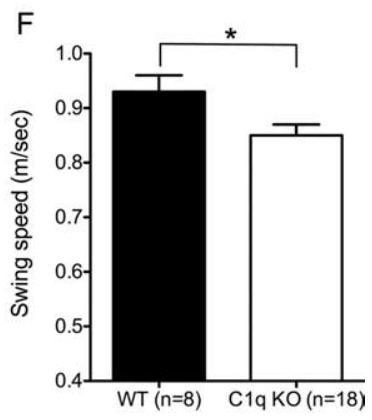

Figure 3. $\quad \mathrm{C} 1 \mathrm{q} \mathrm{KO}$ mice show improved recovery in the fine details of gait as assessed by CatWalk. $\boldsymbol{A}-\boldsymbol{C}$, No significant differ-

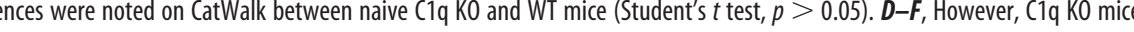

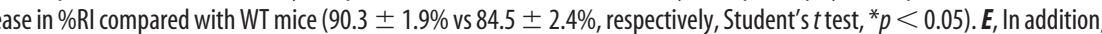
swing speed of the hindlimbs compared with WT mice $\left(0.85 \mathrm{~m} / \mathrm{s} \pm 0.02 \mathrm{vs} 0.93 \mathrm{~m} / \mathrm{s} \pm 0.03\right.$, respectively, Student's $t$ test, ${ }^{*} p<$ 0.05). Error bars represent group means \pm SEM.
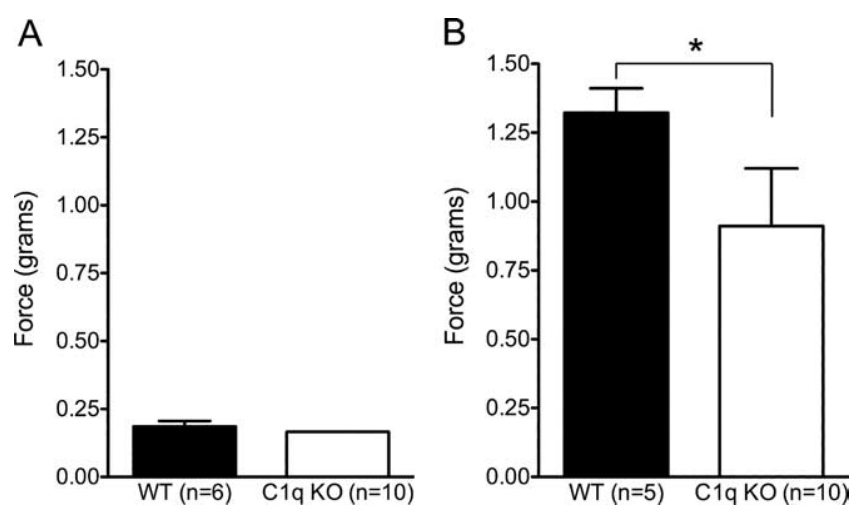

Figure 4. $\quad \mathrm{C} 1 \mathrm{q} \mathrm{KO}$ mice recover greater hindlimb sensory function than WT mice. Von Frey filament testing was performed to assess hindlimb sensory function. $\boldsymbol{A}$, There was no significant difference in the magnitude of the force necessary to elicit a hind paw withdrawal in naive animals (Student's $t$ test $p>0.05$ ). B, After SCl, 28 d post-injury, the force required to elicit a hind paw withdrawal in C1q K0 mice was significantly lower than for WT mice (Student's $t$ test, $\left.{ }^{*} p<0.05\right)$. Error bars represent group means \pm SEM.

neutrophils between groups $3 \mathrm{~d}$ post-SCI (Fig. $8 \mathrm{~B}$ ) (Student's $t$ test, $p>0.05)$. Surprisingly, the percentage of microglia/macrophages was greater in $\mathrm{BUB} \mathrm{Clq} \mathrm{KO}(2.7 \pm 0.2 \%)$ mice compared with BUB WT $(1.8 \pm 0.2 \%)$ mice (Fig. $8 C$ ) (Student's $t$ test, $p<$ $0.01) 3 \mathrm{~d}$ post-SCI. Representative flow cytometric scatter plots of microglia/macrophages are shown in Figure $8 D$. To investigate whether the microglia/macrophage response was transient or prolonged, spinal cord tissue sections obtained $28 \mathrm{~d}$ post-injury were immunolabeled with F4/80 antibody. Unbiased stereologi- 


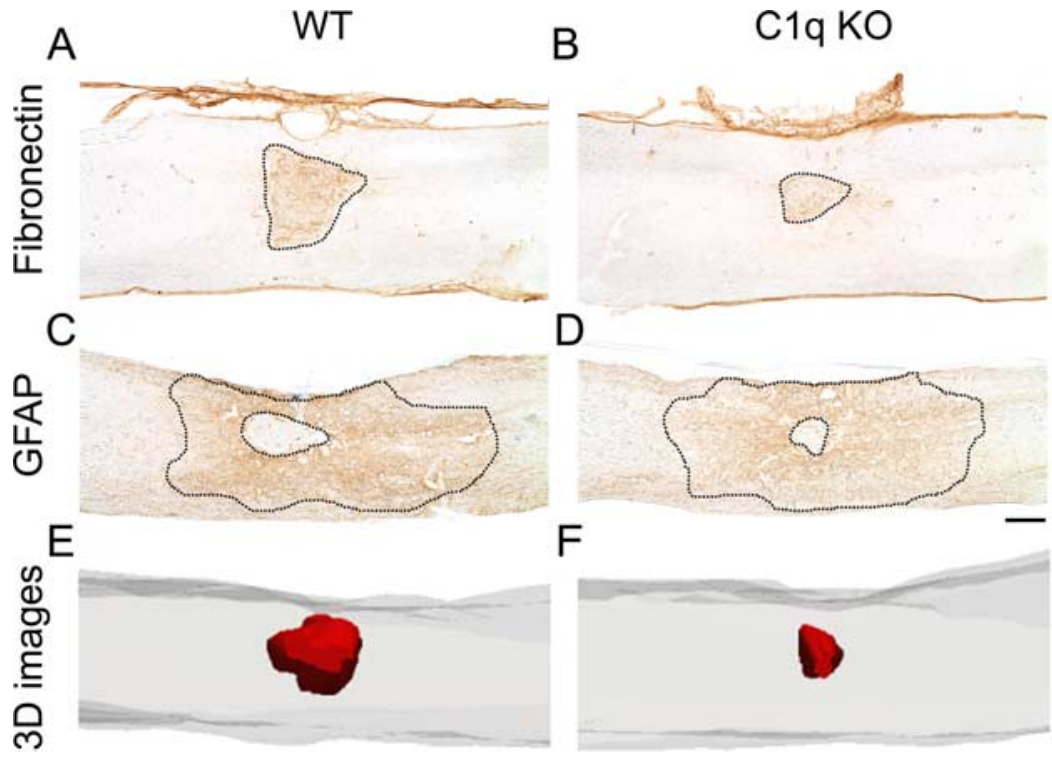

Figure 5. C1q K0 mice show reduced pathology $28 \mathrm{~d}$ post-SCI. $A-D$, Low power photomicrographs of representative fibronectin and GFAP immunostained parasagittal spinal cord sections. Note the reduced fibronectin immunopositive area in $\mathrm{C} 1 \mathrm{q}$ KO $(\boldsymbol{B})$ compared with WT $(\boldsymbol{A})$. C $\boldsymbol{C}$, GFAP immunostained sections illustrate the reduced central core lesion in $\mathrm{C1q}$ KO mice and the extensive glial scar that spreads rostral and caudal to the injury epicenter. $\boldsymbol{E}-\boldsymbol{F}$, Three-dimensional (3-D) reconstructions of representative injured spinal cord segments illustrate the reduced fibronectin lesion volume (red shading) in C1q KO mice $(\boldsymbol{F})$ compared with WT mice (E). Scale bar, $250 \mu \mathrm{m}$.
A

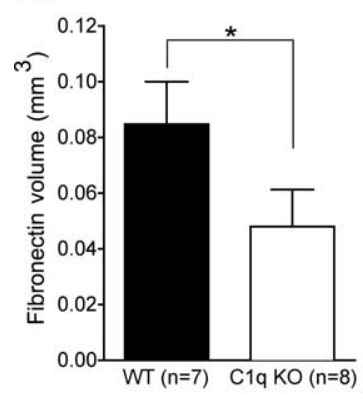

C

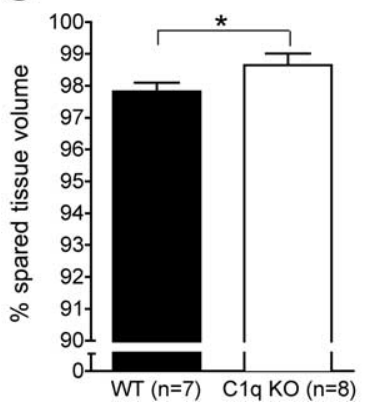

\section{B}

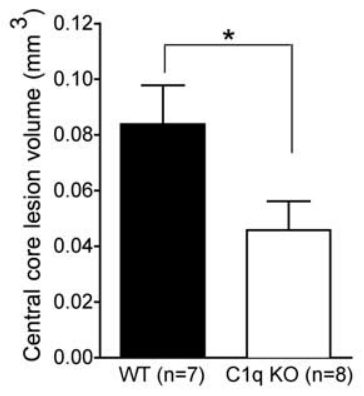

D

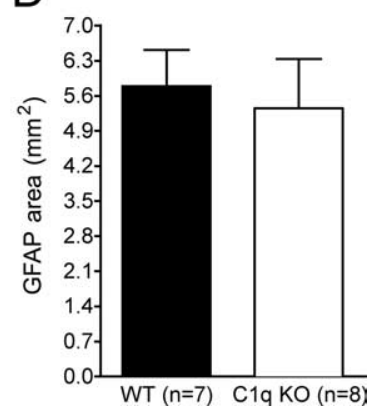

Figure 6. Unbiased stereological quantification of pathology $28 \mathrm{~d}$ post-SCl. $\boldsymbol{A}, \mathrm{C} 1 \mathrm{q}$ KO mice showed a significant reduction in fibronectin volume compared with WT mice (Student's $t$ test, $\left.{ }^{*} p<0.05\right)$. $\boldsymbol{B}$, This finding was corroborated by the significant reduction in the central core lesion volume observed in C1q KO mice compared with WT mice (Student's $t$ test, ${ }^{*} p<0.05$ ). C, Additionally, $\mathrm{C} 1 \mathrm{q}$ KO mice showed a significant increase in spared tissue volume compared with WT mice (Student's $t$ test, ${ }^{*} p<0.05$ ). $\boldsymbol{D}$, However, the GFAP area was not significantly different between the groups (Student's $t$ test, $p>0.05$ ). Error bars represent group means $\pm S E M$.

cal assessment of F4/80 labeled cells revealed no significant difference between BUB WT $(40,261 \pm 4614)$ and BUB C1q KO $(44,213 \pm 8035)$ animals suggesting that the microglia/macrophage response was transient (Fig. 9) (Student's $t$ test, $p>0.05$ ).
Together, these data suggest that the absence of $\mathrm{Clq}$ affects early microglia/macrophage infiltration shortly after SCI.

\section{Discussion}

Genetic variations in mouse strains are known to influence the pathophysiology associated with trauma and disease (Schauwecker and Steward, 1997; Hsiao, 1998; Shuttleworth and Connor, 2001; Mitchell et al., 2002; Ma et al., 2004; Kigerl et al., 2006). Adding to this complexity are studies reporting that total complement activity in serum is low among common laboratory mouse strains compared with rats and humans (Ong and Mattes, 1989; Ong et al., 1992). These findings initially garnered a great deal of attention but the potential consequences for studies involving transgenic models have been largely overlooked. The hemolytic/classical complement activity data presented here are in accordance with previous published findings and showed that male BUB mice exhibited greater complement activity compared with female BUB mice or to either male or female BL/6 mice (Ong and Mattes, 1989; Ong et al., 1992; Ish et al., 1993). Additionally, our studies confirm a previous report (Osmers et al., 2006) that diversity in complement activity between male BUB and male BL/6 mice is not influenced by C3. Moreover, our studies suggest that the low total complement activity in male $\mathrm{BL} / 6$ mice as assessed by $\mathrm{CH} 50$ assays may be partially attributed to a reduction in $\mathrm{C} 5$ activity. These findings are in accordance with studies suggesting that differences in total classical complement activity between these strains may result from variations in terminal complement components (Churchill et al., 1967; Nilsson and Müller-Eberhard, 1967a,b; Osmers et al., 2006).

To evaluate the effects of genetic background on complement activation in SCI, total complement activity was measured $24 \mathrm{~h}$ after SCI in mice with low (female BUB and male BL/6) versus high (male BUB) complement activity and compared with naive animals of the same strain/gender. Only male BUB mice exhibited complement consumption $24 \mathrm{~h}$ after SCI. These data suggested that low levels of total classical complement activity may alter the contribution of complement to the pathophysiology of $\mathrm{SCI}$. Therefore, to investigate the role of C1q in SCI, C1q KO mice on mixed BL/ 6 background were backcrossed onto the complement sufficient BUB background

The data presented here are the first to investigate the role of the classical complement pathway in SCI. This study demonstrates that deficiency in the recognition component of the classical complement pathway $(\mathrm{Clq})$ improves locomotor recovery. Improved recovery was also associated with a decreased threshold for withdrawal from a mild stimulus using von Frey testing. Furthermore, BUB C1q KO mice showed a significant reduction in lesion volume and increased spared tissue as measured by unbiased stereological methods. Surprisingly, assessment of macrophage infiltration by FACS analysis showed that BUB C1q KO mice exhibited a significantly greater percentage of F4/80 labeled macrophages in the injured spinal cord compared with BUB WT mice $3 \mathrm{~d}$ post-SCI. However, this response appeared to be transient as stereological assessment of spinal cord tissue obtained 28 

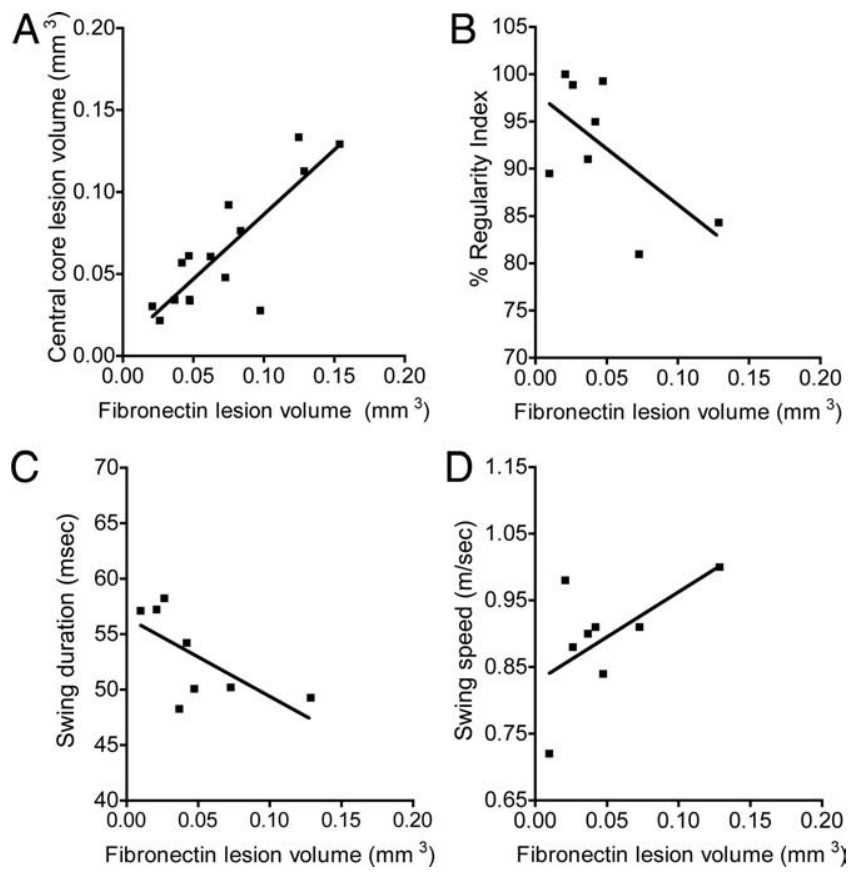

Figure 7. Correlational analyses of behavioral recovery and stereological assessment of lesion volume. $\boldsymbol{A}$, The regression line of fibronectin lesion volume and central core lesion volume revealed a strong positive linear relationship between these two quantitative measures of lesion volume (Pearson: $r=0.839, p<0.0001) . B, C$, Linear regression analysis for C1q K0 mice revealed a significant negative correlation between fibronectin lesion volume versus regularity index and swing duration (Pearson: fibronectin lesion volume vs regularity index, $r=-0.61$, $p=0.049$; fibronectin lesion volume vs swing duration, $r=-0.66, p=0.038$ ). $\boldsymbol{D}$, Additionally, regression analysis for $\mathrm{C} 1 \mathrm{q} \mathrm{KO}$ mice revealed a trend for a positive correlation for fibronectin lesion volume versus swing speed (Pearson, $r=0.59, p=0.062$ ). Data points represent individual animals.

d post-injury revealed no differences in the number of F4/80positive cells between groups.

Complement proteins are involved in a myriad of functions in disease and trauma models of the CNS system. Previous studies have shown that complement activation mediates recruitment of inflammatory cells such as neutrophils and macrophages through the generation of the anaphylatoxins (C3a and C5a). Activated neutrophils and microglia/macrophages have been implicated in mediating neuronal and glial cell death through the release of potentially toxic products (Newman et al., 2001; Liu et al., 2002; Shamash et al., 2002; Hendriks et al., 2005). In addition, neurons (Singhrao et al., 2000) and oligodendrocytes (Wing et al., 1992; Piddlesden and Morgan, 1993; Agoropoulou et al., 1998) have been reported to be susceptible to MAC mediated cell death. MAC is a series of complement proteins that assemble auto-catalytically and has the capacity to cause cell loss and therefore contribute to tissue damage and ultimately lesion volume. Given that the prominent histological features observed after SCI are cellular immune infiltration and tissue damage, we sought to investigate in this study whether the classical complement pathway affects locomotor recovery, tissue damage and the cellular inflammatory response following a mild contusion injury.

The degree of functional recovery observed after contusion induced SCI is highly dependent on the extent of tissue damage. Numerous studies have shown that mild contusion injuries cause tissue damage that is predominantly restricted to the dorsal white matter and the central gray matter (Noble and Wrathall, 1989; Basso et al., 1996; Jakeman et al., 2000; Hutchinson et al., 2001; Kloos et al., 2005; Jakeman et al., 2006). The dorsal fiber tracts that are thus mostly affected by a mild contusion injury are the corticospinal and propriospinal tracts. The corticospinal and the propriospinal tracts are thought to be involved in fine voluntary movement and less involved in gross locomotion (Bregman et al., 1995; Metz et al., 2000; Weidner et al., 2001; Loy et al., 2002; Hendriks et al., 2006). BUB C1q KO showed improved recovery on the fine details of gait as measured by CatWalk that were not reflected on the BMS scale. These findings illustrate the importance of using behavioral tests that are sensitive to the deficits predicted to be associated with a particular injury severity. Although this study highlights recovery of locomotor function in a mid-thoracic contusion injury, a large percentage of the SCI population have cervical injuries. For example, the 50\% reduction in lesion volume observed in the absence of $\mathrm{Clq}$ after a T9 contusion injury would have a dramatic behavioral effect in a cervical injury model and thus could potentially translate clinically into recovery of precision grip and independent finger movements for people with cervical injuries.

It has been suggested that as little as a $10 \%$ increase in tissue sparing could be sufficient for recovery of stepping ability in rats (Bresnahan et al., 1987; Blight, 1993; Fehlings and Tator, 1995; Kloos et al., 2005). These data imply that sparing a small fraction of the descending axons would be instrumental to recovery of locomotor function. Moreover, our results suggest that reducing lesion volume may also improve locomotor recovery. Additionally, there is a high degree of correlation between white matter sparing and behavioral recovery after contusion SCI in rats (Bresnahan et al., 1987; Noble and Wrathall, 1989; Basso et al., 1996), and previous studies have suggested a role for complement in EAE, a demyelinating disease of the CNS (Nataf et al., 2000; Mead et al., 2002; Tran et al., 2002). Thus, reduction of complement-mediated oligodendrocyte death would be predicted to ameliorate demyelination and axonal loss, suggesting one mechanism for improved locomotor function in BUB C1q $\mathrm{KO}$ versus BUB WT mice.

BUB C1q KO mice did not show a reduction in neutrophil infiltration $24 \mathrm{~h}$ and $3 \mathrm{~d}$ post-SCI as assessed by FACS analysis. These observations are in contrast to previous studies in which $\mathrm{Clq} \mathrm{KO}$ mice were shown to have reduced neutrophil infiltration $24 \mathrm{~h}$ post-traumatic brain injury (Ten et al., 2005). In addition, previous studies have demonstrated a role for C1q in mediating neutrophil chemotaxis (Leigh et al., 1998) in vitro. However, the most potent neutrophil chemotactic molecule is the complement anaphylatoxin C5a (Guo and Ward, 2006). Thus, neutrophil infiltration after SCI in BUB C1q KO mice may be mediated by anaphylatoxins that could be produced upon activation of the alternative pathway or the thrombin pathway (Huber-Lang et al., 2006).

In contrast to the data obtained for neutrophils, we observed a small, yet, significant increase in microglia/macrophages $3 \mathrm{~d}$ post-SCI. However, the increased microglia/macrophage response appears to be transient as stereological assessment of spinal cord tissue obtained $28 \mathrm{~d}$ post-injury revealed no difference in F4/80-positive cells between groups. The increased microglia/ macrophage response may be related to an increased number of splenic monocytes detected in $\mathrm{Clq} \mathrm{KO}$ mice (Trendelenburg et al., 2004) however, in the present study we did not differentiate between resident microglia and recruited macrophages. This phenotype has been suggested to be a compensatory developmental mechanism for the absence of C1q (Trendelenburg et al., 2004). The role of microglia/macrophages after SCI is complex and data testing the role of these cells in SCI pathogenesis has yielded conflicting results. Macrophages may promote tissue 

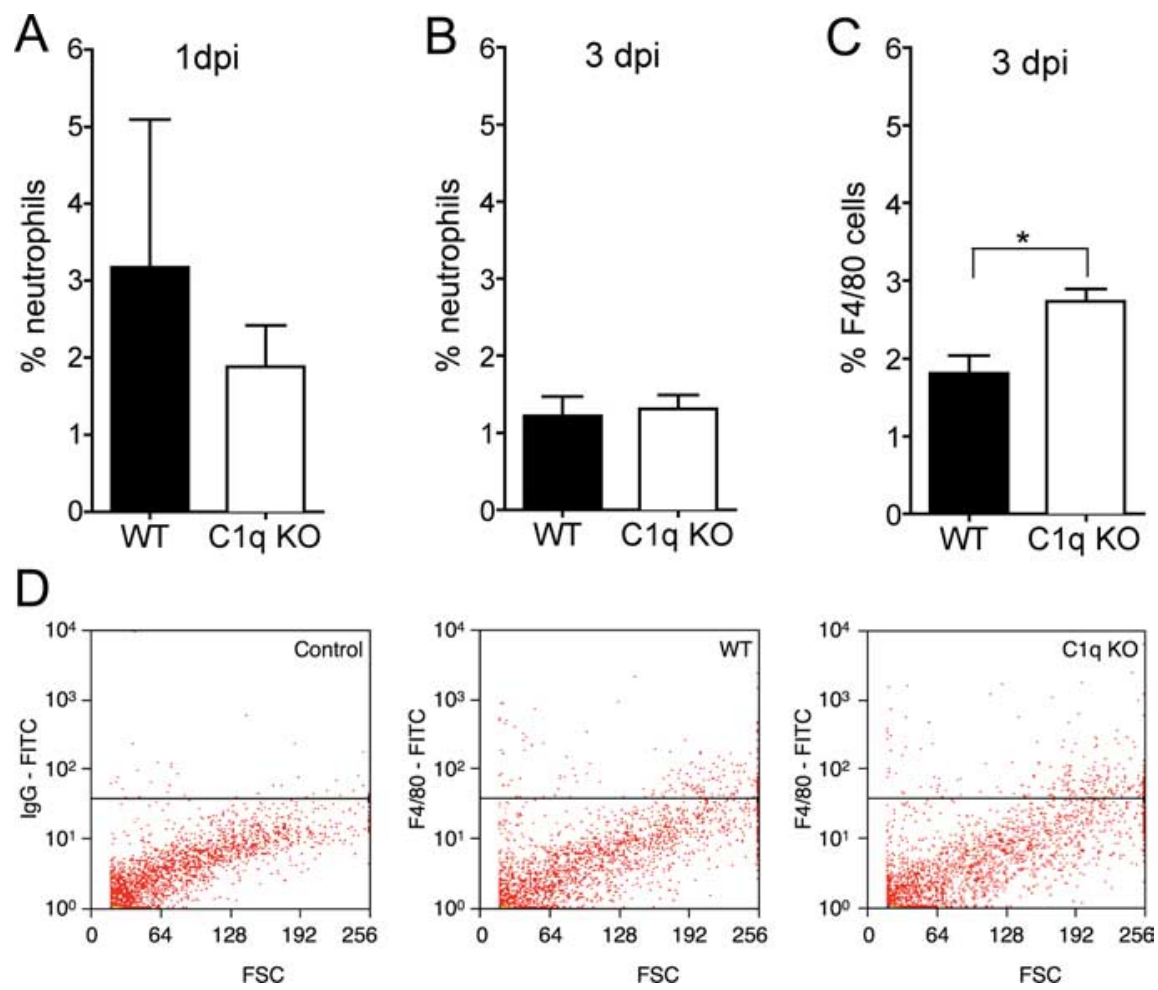

Figure 8. The microglia/macrophage (F4/80) response is increased in C1q K0 mice $3 \mathrm{~d}$ post-SCI. $\boldsymbol{A}$, No significant differences in the percentage of neutrophils in the spinal cords were noted between C $1 q$ KO $(n=4)$ and WT $(n=4)$ mice $1 \mathrm{~d}$ post-SCI (Student's $t$ test, $p>0.05)$. $B$, Additionally, no significant differences in the percentage of neutrophils were noted between $\mathrm{C} 1 \mathrm{q}$ KO $(n=6)$ and WT $(n=5)$ mice 3 d post-SCI (Student's $t$ test, $p>0.05)$. C, C1q KO $(n=9)$ mice showed a significant increase in the percentage of F4/80-positive microglia/macrophage compared with WT $(n=6)$ mice $3 \mathrm{~d}$ post-SCI (Student's $t$ test, ${ }^{*} p<0.01$ ). Bars represent group means \pm SEM. D, Representative scatter plots of spinal cord cells labeled with either F4/80 antibody or isotype control.
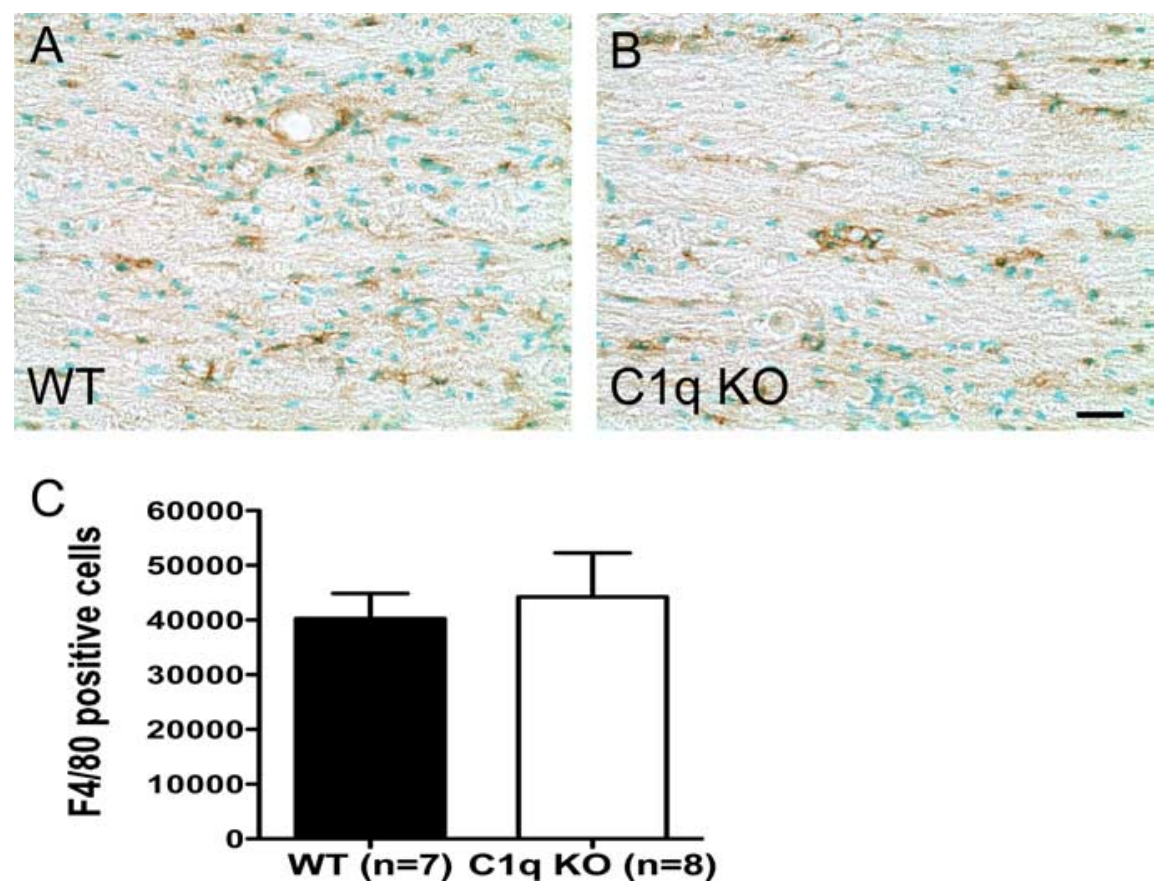

Figure 9. The microglia/macrophage response in C1q K0 mice is similar to WT mice $28 \mathrm{~d}$ post-SCl. $\boldsymbol{A}, \boldsymbol{B}$, Representative photomicrographs of parasagittal spinal cord sections from WT and C1q KO mice immunolabeled with F4/80 antibody and counter-stained with methyl green. $\boldsymbol{C}$, Unbiased stereological quantification of F4/80-positive cells showed that the number of F4/80-positive cells was not significantly different between groups (Student's $t$ test, $p>0.05$ ). Bars represent group means \pm SEM. Scale bar, $25 \mu \mathrm{m}$. damage through the generation of proteases, the release of reactive oxygen intermediates and the synthesis of proinflammatory cytokines (Newman et al., 2001; Liu et al., 2002; Shamash et al., 2002; Hendriks et al., 2005). However, macrophages have also been shown to express a wide variety of growth factors that have been implicated in mediating neuronal and glial cell protection (Nakajima et al., 2001; Nakajima and Kohsaka, 2004; Hashimoto et al., 2005; Glezer et al., 2007; Zhang and Mosser, 2008). In addition, macrophages have been suggested to promote regeneration of injured retinal ganglion cells (Yin et al., 2006) and DRG cells (Lu and Richardson, 1991; Dailey et al., 1998). It is unclear based on our data whether the observed increased microglia/macrophage response observed in BUB Clq $\mathrm{KO}$ mice is beneficial or detrimental to recovery after SCI; further studies testing the effect of macrophage depletion in $\mathrm{BUB} \mathrm{C1q} \mathrm{KO} \mathrm{mice} \mathrm{may}$ be instrumental in this regard.

Recently, a number of SCI studies have reported that activated microglia contribute to neuropathic pain in both peripheral nerve injury (Watkins et al., 2001; Clark et al., 2007; Bura et al., 2008; Dominguez et al., 2008) and SCI (Hains and Waxman, 2006; Peng et al., 2006; Detloff et al., 2008). Moreover, complement activation has been implicated in the development of neuropathic pain in a number of peripheral nerve injury models (Twining et al., 2005; Clark et al., 2006; Griffin et al., 2007; Levin et al., 2008). Although we observed an increased microglia/macrophage response $3 \mathrm{~d}$ post-SCI, there was no difference between groups $28 \mathrm{~d}$ post-injury and von Frey testing at $28 \mathrm{~d}$ showed no evidence that either group developed mechanical allodynia. It has been reported that mechanical allodynia is well established by $14 \mathrm{~d}$ post-SCI and persists for weeks thereafter (Christensen et al., 1996; Christensen and Hulsebosch, 1997; Peng et al., 2006; Detloff et al., 2008); thus von Frey testing at $28 \mathrm{~d}$ should be an adequate time point for allodynia assessment. In contrast, both BUB C1q KO and BUB WT mice required a greater force to elicit a hind paw withdrawal post-injury compared with pre-injury, which is consistent with the loss of hind paw sensory motor function following a mild contusion injury. These data are in agreement with studies reporting that animals receiving mild contusion injuries fail to develop mechanical allodynia (Kloos et al., 2005; Detloff et al., 2008).

The data presented here confirms a previous report that $\mathrm{Cl} \mathrm{q}$ plays a detrimen- 
tal role in the CNS (Fonseca et al., 2004). However, a recent study by Stevens et al. (2007) suggests that C1q may be important during development. Specifically, the authors showed that mice deficient in either C1q or C3 exhibited defects in synapse elimination (Stevens et al., 2007). Moreover, a beneficial role for complement in the CNS has also been attributed to complement protein C5 and MAC (C5b-9). C5 deficient mice were shown to be protected from kainic acid injury (Pasinetti et al., 1996) and against glutamate neurotoxicity (Osaka et al., 1999) and showed less pathology after induction of EAE (Weerth et al., 2003). Although MAC was originally linked exclusively with lytic cell death, evidence suggests that sublethal concentrations of MAC may induce oligodendrocyte proliferation (Rus et al., 1996, 2006; Soane et al., 1999). Together, these data raise the possibility that other complement proteins or pathways may play a beneficial role in SCI.

In summary, these results extend previous findings on the role of the complement cascade in SCI and are the first to implicate the classical complement pathway as a component of the inflammatory response that is detrimental to recovery after SCI. Given the complexity of the complement cascade and evidence for beneficial effects as a result of complement activation in other CNS models, further studies are warranted to investigate the role of other complement components and receptors in SCI.

\section{References}

Ackery A, Robins S, Fehlings MG (2006) Inhibition of Fas-mediated apoptosis through administration of soluble Fas receptor improves functional outcome and reduces posttraumatic axonal degeneration after acute spinal cord injury. J Neurotrauma 23:604-616.

Agoropoulou C, Piddlesden SJ, Lachmann PJ, Wing MG (1998) Neuronal protection of oligodendrocytes from antibody-independent complement lysis. Neuroreport 9:927-932.

Anderson AJ, Robert S, Huang W, Young W, Cotman CW (2004) Activation of complement pathways after contusion-induced spinal cord injury. J Neurotrauma 21:1831-1846.

Basso DM, Beattie MS, Bresnahan JC (1996) Graded histological and locomotor outcomes after spinal cord contusion using the NYU weight-drop device versus transection. Exp Neurol 139:244-256.

Basso DM, Fisher LC, Anderson AJ, Jakeman LB, McTigue DM, Popovich PG (2006) Basso Mouse Scale for locomotion detects differences in recovery after spinal cord injury in five common mouse strains. J Neurotrauma 23:635-659.

Blight AR (1993) Remyelination, revascularization, and recovery of function in experimental spinal cord injury. Adv Neurol 59:91-104.

Boos L, Campbell IL, Ames R, Wetsel RA, Barnum SR (2004) Deletion of the complement anaphylatoxin C3a receptor attenuates, whereas ectopic expression of $\mathrm{C} 3 \mathrm{a}$ in the brain exacerbates, experimental autoimmune encephalomyelitis. J Immunol 173:4708-4714.

Botto M, Dell'Agnola C, Bygrave AE, Thompson EM, Cook HT, Petry F, Loos M, Pandolfi PP, Walport MJ (1998) Homozygous C1q deficiency causes glomerulonephritis associated with multiple apoptotic bodies. Nat Genet 19:56-59.

Bregman BS, Kunkel-Bagden E, Schnell L, Dai HN, Gao D, Schwab ME (1995) Recovery from spinal cord injury mediated by antibodies to neurite growth inhibitors. Nature 378:498-501.

Bresnahan JC, Beattie MS, Todd FD 3rd, Noyes DH (1987) A behavioral and anatomical analysis of spinal cord injury produced by a feedbackcontrolled impaction device. Exp Neurol 95:548-570.

Bura SA, Nadal X, Ledent C, Maldonado R, Valverde O (2008) A(2A) adenosine receptor regulates glia proliferation and pain after peripheral nerve injury. Pain 140:95-103.

Cao Y, Shumsky JS, Sabol MA, Kushner RA, Strittmatter S, Hamers FP, Lee DH, Rabacchi SA, Murray M (2008) Nogo-66 receptor antagonist peptide (NEP1-40) administration promotes functional recovery and axonal growth after lateral funiculus injury in the adult rat. Neurorehabil Neural Repair 22:262-278.

Carroll MC (2004) The complement system in regulation of adaptive immunity. Nat Immunol 5:981-986.
Casha S, Yu WR, Fehlings MG (2005) FAS deficiency reduces apoptosis, spares axons and improves function after spinal cord injury. Exp Neurol 196:390-400.

Chaplan SR, Bach FW, Pogrel JW, Chung JM, Yaksh TL (1994) Quantitative assessment of tactile allodynia in the rat paw. J Neurosci Methods 53:5563.

Christensen MD, Hulsebosch CE (1997) Chronic central pain after spinal cord injury. J Neurotrauma 14:517-537.

Christensen MD, Everhart AW, Pickelman JT, Hulsebosch CE (1996) Mechanical and thermal allodynia in chronic central pain following spinal cord injury. Pain 68:97-107.

Churchill WH Jr, Weintrau RM, Borsos T, Rapp HJ (1967) Mouse complement: the effect of sex hormones and castration on two of the late-acting components. J Exp Med 125:657-672.

Clark AK, Gentry C, Bradbury EJ, McMahon SB, Malcangio M (2007) Role of spinal microglia in rat models of peripheral nerve injury and inflammation. Eur J Pain 11:223-230.

Clark JD, Qiao Y, Li X, Shi X, Angst MS, Yeomans DC (2006) Blockade of the complement C5a receptor reduces incisional allodynia, edema, and cytokine expression. Anesthesiology 104:1274-1282.

Crutcher KA, Gendelman HE, Kipnis J, Perez-Polo JR, Perry VH, Popovich PG, Weaver LC (2006) Debate: "is increasing neuroinflammation beneficial for neural repair?” J Neuroimmune Pharmacol 1:195-211.

Dailey AT, Avellino AM, Benthem L, Silver J, Kliot M (1998) Complement depletion reduces macrophage infiltration and activation during Wallerian degeneration and axonal regeneration. J Neurosci 18:6713-6722.

Detloff MR, Fisher LC, McGaughy V, Longbrake EE, Popovich PG, Basso DM (2008) Remote activation of microglia and pro-inflammatory cytokines predict the onset and severity of below-level neuropathic pain after spinal cord injury in rats. Exp Neurol 212:337-347.

Dodds AW, Sim RB (1997) Complement: a practical approach. Oxford; New York: IRL at Oxford UP.

Dominguez E, Rivat C, Pommier B, Mauborgne A, Pohl M (2008) JAK/ STAT3 pathway is activated in spinal cord microglia after peripheral nerve injury and contributes to neuropathic pain development in rat. J Neurochem 107:50-60.

Donnelly DJ, Popovich PG (2008) Inflammation and its role in neuroprotection, axonal regeneration and functional recovery after spinal cord injury. Exp Neurol 209:378-388.

Farooque M, Isaksson J, Olsson Y (2001) White matter preservation after spinal cord injury in ICAM-1/P-selectin-deficient mice. Acta Neuropathol 102:132-140.

Fehlings MG, Tator CH (1995) The relationships among the severity of spinal cord injury, residual neurological function, axon counts, and counts of retrogradely labeled neurons after experimental spinal cord injury. Exp Neurol 132:220-228.

Fonseca MI, Zhou J, Botto M, Tenner AJ (2004) Absence of C1q leads to less neuropathology in transgenic mouse models of Alzheimer's disease. J Neurosci 24:6457-6465.

Genovese T, Mazzon E, Crisafulli C, Di Paola R, Muià C, Esposito E, Bramanti P, Cuzzocrea S (2008) TNF-alpha blockage in a mouse model of SCI: evidence for improved outcome. Shock 29:32-41.

Glezer I, Simard AR, Rivest S (2007) Neuroprotective role of the innate immune system by microglia. Neuroscience 147:867-883.

Gonzalez R, Glaser J, Liu MT, Lane TE, Keirstead HS (2003) Reducing inflammation decreases secondary degeneration and functional deficit after spinal cord injury. Exp Neurol 184:456-463.

Goodfellow RM, Williams AS, Levin JL, Williams BD, Morgan BP (1997) Local therapy with soluble complement receptor 1 (sCR1) suppresses inflammation in rat mono-articular arthritis. Clin Exp Immunol 110:45-52.

Griffin RS, Costigan M, Brenner GJ, Ma CH, Scholz J, Moss A, Allchorne AJ, Stahl GL, WoolfCJ (2007) Complement induction in spinal cord microglia results in anaphylatoxin C5a-mediated pain hypersensitivity. J Neurosci 27:8699-8708.

Guo RF, Ward PA (2006) C5a, a therapeutic target in sepsis. Recent Patents Anti-Infect Drug Disc 1:57-65.

Hains BC, Waxman SG (2006) Activated microglia contribute to the maintenance of chronic pain after spinal cord injury. J Neurosci 26:4308-4317.

Hamada Y, Ikata T, Katoh S, Katoh K, Niwa M, Tsutsumishita Y, Fukuzawa K 
(1996) Effects of exogenous transforming growth factor-beta 1 on spinal cord injury in rats. Neurosci Lett 203:97-100.

Hamers FP, Lankhorst AJ, van Laar TJ, Veldhuis WB, Gispen WH (2001) Automated quantitative gait analysis during overground locomotion in the rat: its application to spinal cord contusion and transection injuries. J Neurotrauma 18:187-201.

Hashimoto M, Nitta A, Fukumitsu H, Nomoto H, Shen L, Furukawa S (2005) Involvement of glial cell line-derived neurotrophic factor in activation processes of rodent macrophages. J Neurosci Res 79:476-487.

Hendriks JJ, Teunissen CE, de Vries HE, Dijkstra CD (2005) Macrophages and neurodegeneration. Brain Res Brain Res Rev 48:185-195.

Hendriks WT, Eggers R, Ruitenberg MJ, Blits B, Hamers FP, Verhaagen J, Boer GJ (2006) Profound differences in spontaneous long-term functional recovery after defined spinal tract lesions in the rat. J Neurotrauma 23:18-35.

Howard CV, Reed MG (1998) Unbiased stereology, 3-D measurements in microscopy. Oxford: Garland Sciences/Bios Scientific.

Hsiao K (1998) Strain dependent and invariant features of transgenic mice expressing Alzheimer amyloid precursor proteins. Prog Brain Res 117:335-341.

Huber-Lang M, Sarma JV, Zetoune FS, Rittirsch D, Neff TA, McGuire SR, Lambris JD, Warner RL, Flierl MA, Hoesel LM, Gebhard F, Younger JG, Drouin SM, Wetsel RA, Ward PA (2006) Generation of C5a in the absence of C3: a new complement activation pathway. Nat Med 12:682-687.

Hutchinson KJ, Linderman JK, Basso DM (2001) Skeletal muscle adaptations following spinal cord contusion injury in rat and the relationship to locomotor function: a time course study. J Neurotrauma 18:1075-1089.

Ish C, Ong GL, Desai N, Mattes MJ (1993) The specificity of alternative complement pathway-mediated lysis of erythrocytes: a survey of complement and target cells from 25 species. Scand J Immunol 38:113-122.

Jakeman LB, Guan Z, Wei P, Ponnappan R, Dzwonczyk R, Popovich PG, Stokes BT (2000) Traumatic spinal cord injury produced by controlled contusion in mouse. J Neurotrauma 17:299-319.

Jakeman LB, Chen Y, Lucin KM, McTigue DM (2006) Mice lacking L1 cell adhesion molecule have deficits in locomotion and exhibit enhanced corticospinal tract sprouting following mild contusion injury to the spinal cord. Eur J Neurosci 23:1997-2011.

Kigerl KA, McGaughy VM, Popovich PG (2006) Comparative analysis of lesion development and intraspinal inflammation in four strains of mice following spinal contusion injury. J Comp Neurol 494:578-594.

Kloos AD, Fisher LC, Detloff MR, Hassenzahl DL, Basso DM (2005) Stepwise motor and all-or-none sensory recovery is associated with nonlinear sparing after incremental spinal cord injury in rats. Exp Neurol 191:251-265.

Koopmans GC, Deumens R, Honig WM, Hamers FP, Steinbusch HW, Joosten EA (2005) The assessment of locomotor function in spinal cord injured rats: the importance of objective analysis of coordination. J Neurotrauma 22:214-225.

Leigh LE, Ghebrehiwet B, Perera TP, Bird IN, Strong P, Kishore U, Reid KB, Eggleton P (1998) Clq-mediated chemotaxis by human neutrophils: involvement of gClqR and G-protein signalling mechanisms. Biochem J 330:247-254.

Levin ME, Jin JG, Ji RR, Tong J, Pomonis JD, Lavery DJ, Miller SW, Chiang LW (2008) Complement activation in the peripheral nervous system following the spinal nerve ligation model of neuropathic pain. Pain 137:182-201.

Liebscher T, Schnell L, Schnell D, Scholl J, Schneider R, Gullo M, Fouad K, Mir A, Rausch M, Kindler D, Hamers FP, Schwab ME (2005) Nogo-A antibody improves regeneration and locomotion of spinal cord-injured rats. Ann Neurol 58:706-719.

Liu B, Gao HM, Wang JY, Jeohn GH, Cooper CL, Hong JS (2002) Role of nitric oxide in inflammation-mediated neurodegeneration. Ann N Y Acad Sci 962:318-331.

Loy DN, Crawford CH, Darnall JB, Burke DA, Onifer SM, Whittemore SR (2002) Temporal progression of angiogenesis and basal lamina deposition after contusive spinal cord injury in the adult rat. J Comp Neurol 445:308-324.

Lu X, Richardson PM (1991) Inflammation near the nerve cell body enhances axonal regeneration. J Neurosci 11:972-978.

Ma M, Basso DM, Walters P, Stokes BT, Jakeman LB (2001) Behavioral and histological outcomes following graded spinal cord contusion injury in the C57BL/6 mouse. Exp Neurol 169:239-254.
Ma M, Wei T, Boring L, Charo IF, Ransohoff RM, Jakeman LB (2002) Monocyte recruitment and myelin removal are delayed following spinal cord injury in mice with CCR2 chemokine receptor deletion. J Neurosci Res 68:691-702.

Ma M, Wei P, Wei T, Ransohoff RM, Jakeman LB (2004) Enhanced axonal growth into a spinal cord contusion injury site in a strain of mouse (129X1/SvJ) with a diminished inflammatory response. J Comp Neurol 474:469-486.

Mead RJ, Singhrao SK, Neal JW, Lassmann H, Morgan BP (2002) The membrane attack complex of complement causes severe demyelination associated with acute axonal injury. J Immunol 168:458-465.

Metz GA, Curt A, van de Meent H, Klusman I, Schwab ME, Dietz V (2000) Validation of the weight-drop contusion model in rats: a comparative study of human spinal cord injury. J Neurotrauma 17:1-17.

Mills CD, Grady JJ, Hulsebosch CE (2001) Changes in exploratory behavior as a measure of chronic central pain following spinal cord injury. J Neurotrauma 18:1091-1105.

Mitchell DA, Pickering MC, Warren J, Fossati-Jimack L, Cortes-Hernandez J, Cook HT, Botto M, Walport MJ (2002) Clq deficiency and autoimmunity: the effects of genetic background on disease expression. J Immunol 168:2538-2543.

Mizuno M, Nishikawa K, Morgan BP, Matsuo S (2000) Comparison of the suppressive effects of soluble CR1 and C5a receptor antagonist in acute arthritis induced in rats by blocking of CD59. Clin Exp Immunol 119:368-375.

Morgan BP, Marchbank KJ, Longhi MP, Harris CL, Gallimore AM (2005) Complement: central to innate immunity and bridging to adaptive responses. Immunol Lett 97:171-179.

Mulligan MS, Yeh CG, Rudolph AR, Ward PA (1992) Protective effects of soluble CR1 in complement- and neutrophil-mediated tissue injury. J Immunol 148:1479-1485.

Nakajima K, Kohsaka S (2004) Microglia: neuroprotective and neurotrophic cells in the central nervous system. Curr Drug Targets Cardiovasc Haematol Disord 4:65-84.

Nakajima K, Honda S, Tohyama Y, Imai Y, Kohsaka S, Kurihara T (2001) Neurotrophin secretion from cultured microglia. J Neurosci Res 65:322-331.

Nataf S, Carroll SL, Wetsel RA, Szalai AJ, Barnum SR (2000) Attenuation of experimental autoimmune demyelination in complement-deficient mice. J Immunol 165:5867-5873.

Newman TA, Woolley ST, Hughes PM, Sibson NR, Anthony DC, Perry VH (2001) T-cell- and macrophage-mediated axon damage in the absence of a CNS-specific immune response: involvement of metalloproteinases. Brain 124:2203-2214.

Niculescu T, Weerth S, Soane L, Niculescu F, Rus V, Raine CS, Shin ML, Rus H (2003) Effects of membrane attack complex of complement on apoptosis in experimental autoimmune encephalomyelitis. Ann N Y Acad Sci 1010:530-533.

Nguyen HX, Galvan MD, Anderson AJ (2008) Characterization of early and terminal complement proteins associated with polymorphonuclear leukocytes in vitro and in vivo after spinal cord injury. J Neuroinflammation $5: 26$.

Nilsson UR, Müller-Eberhard HJ (1967a) Deficiency of the fifth component of complement in mice with an inherited complement defect. J Exp Med 125:1-16.

Nilsson UR, Müller-Eberhard HJ (1967b) Studies on the mode of action of the fifth, sixth and seventh component of human complement in immune haemolysis. Immunology 13:101-117.

Noble LJ, Wrathall JR (1989) Correlative analyses of lesion development and functional status after graded spinal cord contusive injuries in the rat. Exp Neurol 103:34-40.

Ong GL, Mattes MJ (1989) Mouse strains with typical mammalian levels of complement activity. J Immunol Methods 125:147-158.

Ong GL, Baker AE, Mattes MJ (1992) Analysis of high complement levels in Mus hortulanus and BUB mice. J Immunol Methods 154:37-45.

Osaka H, Mukherjee P, Aisen PS, Pasinetti GM (1999) Complementderived anaphylatoxin C5a protects against glutamate-mediated neurotoxicity. J Cell Biochem 73:303-311.

Osmers I, Szalai AJ, Tenner AJ, Barnum SR (2006) Complement in BuB/BnJ mice revisited: serum C3 levels and complement opsonic activity are not elevated. Mol Immunol 43:1722-1725.

Pasinetti GM, Tocco G, Sakhi S, Musleh WD, DeSimoni MG, Mascarucci P, 
Schreiber S, Baudry M, Finch CE (1996) Hereditary deficiencies in complement $\mathrm{C} 5$ are associated with intensified neurodegenerative responses that implicate new roles for the C-system in neuronal and astrocytic functions. Neurobiol Dis 3:197-204.

Peng XM, Zhou ZG, Glorioso JC, Fink DJ, Mata M (2006) Tumor necrosis factor-alpha contributes to below-level neuropathic pain after spinal cord injury. Ann Neurol 59:843-851.

Piddlesden SJ, Morgan BP (1993) Killing of rat glial cells by complement: deficiency of the rat analogue of CD59 is the cause of oligodendrocyte susceptibility to lysis. J Neuroimmunol 48:169-175.

Piddlesden SJ, Storch MK, Hibbs M, Freeman AM, Lassmann H, Morgan BP (1994) Soluble recombinant complement receptor-1 inhibits inflammation and demyelination in antibody-mediated demyelinating experimental allergic encephalomyelitis. J Immunol 152:5477-5484.

Piddlesden SJ, Jiang S, Levin JL, Vincent A, Morgan BP (1996) Soluble complement receptor 1 (sCR1) protects against experimental autoimmune myasthenia gravis. J Neuroimmunol 71:173-177.

Popovich PG, Guan Z, Wei P, Huitinga I, van Rooijen N, Stokes BT (1999) Depletion of hematogenous macrophages promotes partial hindlimb recovery and neuroanatomical repair after experimental spinal cord injury. Exp Neurol 158:351-365.

Qiao F, Atkinson C, Song H, Pannu R, Singh I, Tomlinson S (2006) Complement plays an important role in spinal cord injury and represents a therapeutic target for improving recovery following trauma. Am J Pathol 169:1039-1047.

Ramaglia V, King RH, Nourallah M, Wolterman R, de Jonge R, Ramkema M, Vigar MA, van der Wetering S, Morgan BP, Troost D, Baas F (2007) The membrane attack complex of the complement system is essential for rapid Wallerian degeneration. J Neurosci 27:7663-7672.

Rebhun J, Madorsky JG, Glovsky MM (1991) Proteins of the complement system and acute phase reactants in sera of patients with spinal cord injury. Ann Allergy 66:335-338.

Reynolds DN, Smith SA, Zhang YP, Lahiri DK, Morassutti DJ, Shields CB, Kotwal GJ (2003) Vaccinia virus complement control protein modulates inflammation following spinal cord injury. Ann N Y Acad Sci 1010:534-539.

Reynolds DN, Smith SA, Zhang YP, Mengsheng Q, Lahiri DK, Morassutti DJ, Shields CB, Kotwal GJ (2004) Vaccinia virus complement control protein reduces inflammation and improves spinal cord integrity following spinal cord injury. Ann N Y Acad Sci 1035:165-178.

Rus H, Cudrici C, Niculescu F, Shin ML (2006) Complement activation in autoimmune demyelination: dual role in neuroinflammation and neuroprotection. J Neuroimmunol 180:9-16.

Rus HG, Niculescu F, Shin ML (1996) Sublytic complement attack induces cell cycle in oligodendrocytes. J Immunol 156:4892-4900.

Saville LR, Pospisil CH, Mawhinney LA, Bao F, Simedrea FC, Peters AA, O’Connell PJ, Weaver LC, Dekaban GA (2004) A monoclonal antibody to CD11d reduces the inflammatory infiltrate into the injured spinal cord: a potential neuroprotective treatment. J Neuroimmunol 156:42-57.

Schauwecker PE, Steward O (1997) Genetic determinants of susceptibility to excitotoxic cell death: implications for gene targeting approaches. Proc Natl Acad Sci U S A 94:4103-4108.

Shamash S, Reichert F, Rotshenker S (2002) The cytokine network of Wal- lerian degeneration: tumor necrosis factor- $\alpha$, interleukin- $\alpha$, and interleukin-1 $\beta$. J Neurosci 22:3052-3060.

Shuttleworth CW, Connor JA (2001) Strain-dependent differences in calcium signaling predict excitotoxicity in murine hippocampal neurons. J Neurosci 21:4225-4236.

Singhrao SK, Neal JW, Rushmere NK, Morgan BP, Gasque P (2000) Spontaneous classical pathway activation and deficiency of membrane regulators render human neurons susceptible to complement lysis. Am J Pathol 157:905-918.

Soane L, Rus H, Niculescu F, Shin ML (1999) Inhibition of oligodendrocyte apoptosis by sublytic C5b-9 is associated with enhanced synthesis of bcl-2 and mediated by inhibition of caspase- 3 activation. J Immunol 163:6132-6138.

Stevens B, Allen NJ, Vazquez LE, Howell GR, Christopherson KS, Nouri N, Micheva KD, Mehalow AK, Huberman AD, Stafford B, Sher A, Litke AM, Lambris JD, Smith SJ, John SW, Barres BA (2007) The classical complement cascade mediates CNS synapse elimination. Cell 131:1164-1178.

Ten VS, Sosunov SA, Mazer SP, Stark RI, Caspersen C, Sughrue ME, Botto M, Connolly ES Jr, Pinsky DJ (2005) Clq-deficiency is neuroprotective against hypoxic-ischemic brain injury in neonatal mice. Stroke 36:2244-2250

Tran GT, Hodgkinson SJ, Carter N, Killingsworth M, Spicer ST, Hall BM (2002) Attenuation of experimental allergic encephalomyelitis in complement component 6-deficient rats is associated with reduced complement C9 deposition, P-selectin expression, and cellular infiltrate in spinal cords. J Immunol 168:4293-4300.

Trendelenburg M, Manderson AP, Fossati-Jimack L, Walport MJ, Botto M (2004) Monocytosis and accelerated activation of lymphocytes in C1qdeficient autoimmune-prone mice. Immunology 113:80-88.

Twining CM, Sloane EM, Schoeniger DK, Milligan ED, Martin D, Marsh H, Maier SF, Watkins LR (2005) Activation of the spinal cord complement cascade might contribute to mechanical allodynia induced by three animal models of spinal sensitization. J Pain 6:174-183.

Watkins LR, Milligan ED, Maier SF (2001) Glial activation: a driving force for pathological pain. Trends Neurosci 24:450-455.

Weerth SH, Rus H, Shin ML, Raine CS (2003) Complement C5 in experimental autoimmune encephalomyelitis (EAE) facilitates remyelination and prevents gliosis. Am J Pathol 163:1069-1080.

Weidner N, Ner A, Salimi N, Tuszynski MH (2001) Spontaneous corticospinal axonal plasticity and functional recovery after adult central nervous system injury. Proc Natl Acad Sci U S A 98:3513-3518.

Wells JE, Rice TK, Nuttall RK, Edwards DR, Zekki H, Rivest S, Yong VW (2003) An adverse role for matrix metalloproteinase 12 after spinal cord injury in mice. J Neurosci 23:10107-10115.

Wing MG, Zajicek J, Seilly DJ, Compston DA, Lachmann PJ (1992) Oligodendrocytes lack glycolipid anchored proteins which protect them against complement lysis. Restoration of resistance to lysis by incorporation of CD59. Immunology 76:140-145.

Yin Y, Henzl MT, Lorber B, Nakazawa T, Thomas TT, Jiang F, Langer R, Benowitz LI (2006) Oncomodulin is a macrophage-derived signal for axon regeneration in retinal ganglion cells. Nat Neurosci 9:843-852.

Zhang X, Mosser DM (2008) Macrophage activation by endogenous danger signals. J Pathol 214:161-178. 